\title{
COVID-19 Reveals Vulnerabilities of the Food-Energy-Water Nexus to Viral Pandemics
}

\author{
Ryan S. D. Calder,* Caitlin Grady, Marc Jeuland, Christine J. Kirchhoff, Rebecca L. Hale,
} and Rebecca L. Muenich

Cite This: https://doi.org/10.1021/acs.estlett.1c00291

Read Online

\section{ACCESS | Lill Metrics \& More | 回 Article Recommendations ｜（） Supporting Information}

ABSTRACT: Food, energy, and water (FEW) sectors are inextricably linked, making one sector vulnerable to disruptions in another. Interactions between FEW systems, viral pandemics, and human health have not been widely studied. We mined scientific and news/media articles for causal relations among FEW and COVID-19 variables and qualitatively characterized system dynamics. Food systems promoted the emergence and spread of COVID-19, leading to illness and death. Major supply-side breakdowns were avoided (likely due to low morbidity/mortality among working-age people). However, COVID-19 and physical distancing disrupted labor and capital inputs and stressed supply

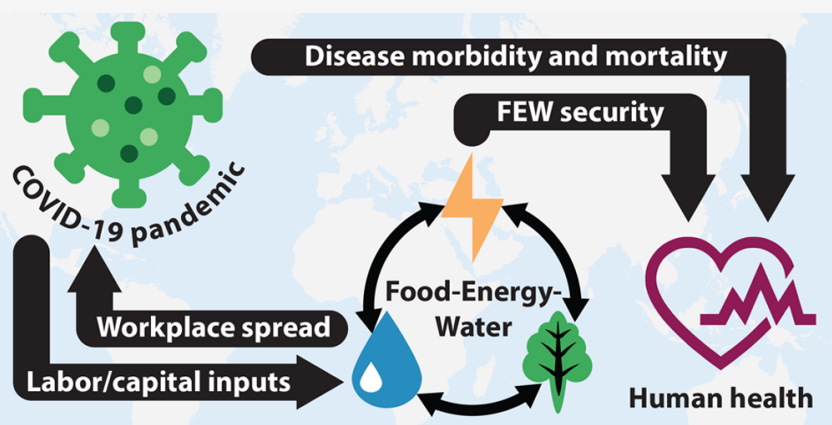
chains, while creating economic insecurity among the already vulnerable poor. This led to demand-side FEW insecurities, in turn increasing susceptibility to COVID-19 among people with many comorbidities. COVID-19 revealed trade-offs such as allocation of water to hygiene versus to food production and disease burden avoided by physical distancing versus disease burden from increased FEW insecurities. News/media articles suggest great public interest in FEW insecurities triggered by COVID-19 interventions among individuals with low COVID-19 case-fatality rates. There is virtually no quantitative analysis of any of these trade-offs or feedbacks. Enhanced quantitative FEW and health models are urgently needed as future pandemics are likely and may have greater morbidity and mortality than COVID-19.

\section{INTRODUCTION}

Modern viral pandemics such as the 2019 coronavirus disease (COVID-19, caused by the virus SARS-CoV-2) are predominantly caused by food systems that expose increasingly interconnected populations to reservoirs of viruses against which humans have little resistance. ${ }^{1}$ As of July 2021, over 190 million cases of COVID-19 have been confirmed globally, resulting in over 4 million deaths. ${ }^{2}$ Attempts to arrest the spread of the virus have meanwhile resulted in widespread economic and social disruption. For example, in the United States, gross domestic product (GDP) fell by an annualized rate of $32 \%$ between the first and second quarters of 2020 as physical distancing and travel restrictions constrained economic activity. ${ }^{3,4}$ COVID-19 demonstrates that modern food systems may disrupt global society by introducing novel pathogens, but interactions with tightly coupled water and energy systems have been underexplored. Characterizing how COVID-19 has influenced food-energy-water (FEW) systems is a first step toward building resilience to avoid catastrophic breakdowns in future pandemics.

Modern food systems promote pandemic zoonoses. Worldwide, animal supply chains create novel contacts between animal species and between animals and humans, promoting viral recombination, bacterial adaptation, and interspecies infection. $^{5-8}$ Low-latitude, less developed countries are biodiverse (with respect to fauna and pathogens) and are subject to social and ecological pressures that increase harvest and consumption of bushmeat, increasing risks of pathogen emergence. ${ }^{1,9-11}$ Virtually all major infectious diseases throughout history such as influenza, measles, and smallpox have been zoonotic and emerged alongside animal husbandry. ${ }^{12-14}$ The continual emergence of new diseases such as HIV/AIDS (1980 to present, >33 million deaths, likely chimpanzee origin), ${ }^{15,16}$ Ebola (1976 to present, $>13000$ deaths over multiple outbreaks, likely bat origin), ${ }^{17-20}$ and SARS-CoV-2/COVID-19 (likely bat origin and pangolin intermediary) ${ }^{21}$ illustrate that emergent zoonotic disease continues to pose novel human health risks.

Current methods to forecast impacts of pandemics on social systems and to understand how policy responses mediate health and wellbeing are inadequate. State-of-the-science

Received: April 19, 2021

Revised: July 20, 2021

Accepted: July 21, 2021 
pandemic management and forecasting tools consider health as a single causal chain between infection, disease, and recovery or death. ${ }^{22}$ Yet policy responses instituted to slow disease spread have diverse consequences with impacts and trade-offs not anticipated at the start of the pandemic. For example, shocks to economic and social networks associated with responses to COVID-19 have caused a serious countervailing mental health risk. In a recent sample of the U.S. population, Czeisler et al. ${ }^{23}$ found that symptoms of anxiety and depression in June 2020 were 3 and 4 times more prevalent, respectively, compared to June 2019 , with $>25 \%$ of respondents aged $18-$ 24 reporting suicidal ideation.

Meanwhile, FEW research is oriented around unsustainable supply-side demand for overexploited resources (especially water) and its impacts on food, energy, and water availability. It is now widely understood that FEW sectors are inextricably linked given the strong dependence of each sector on the other (e.g., agriculture accounts for $71 \%$ of global water withdrawals) and that unsustainable practices in one sector can cause volatility and crises in another (e.g., water shortage-induced food price volatility in 2008-2010)..$^{24,25}$ COVID-19 however reveals that FEW interconnections are vulnerable not just to resource constraints but also to disruptions in human and financial capital on the supply and demand sides. ${ }^{26}$ For instance, economic disruptions in the U.S. led to electric and gas arrearages totaling roughly $\$ 32$ billion by the end of $2020 .^{27}$ Existing FEW modeling tools do not consider the human labor and financial capital required to sustain outputs and are therefore poorly suited to evaluating impacts of pandemics on FEW security.

While both pandemic zoonoses ${ }^{13,28}$ and FEW systems s $^{29,30}$ are major determinants of health globally, their combined effect on health is poorly understood. Pandemic research centers on biophysical processes, some of which have negligible if any impact on health. For example, several recent studies characterized wastewater as a vector of SARS-CoV-2 despite this pathway posing at most a negligible risk. ${ }^{31-36}$ Meanwhile, larger scale processes such as strains on infrastructure and the water insecurity caused by COVID-19related economic precarity have been discussed often in the media but rarely in the scientific literature. Other topics of ongoing research on sector-specific impacts of COVID-19 include impacts on nutritional adequacy ${ }^{37,38}$ and the disproportionate risk of infection faced by workers in the water $^{39}$ and food ${ }^{40,41}$ sectors. While some studies recognize intrasector system dynamics (e.g., risk of an outbreak leading to labor and thus food system disruption in the United States ${ }^{42}$ ), there has been a lack of analysis characterizing crosssector trade-offs, feedbacks, and other system dynamics. This lack of integrated conceptual understanding hinders prediction and management of trade-offs and unintended consequences.

In this paper, we characterize the interactions between FEW processes, COVID-19, and pre-vaccine mitigation measures such as physical distancing and hygiene protocols. We also identify processes that largely withstood the stresses of COVID-19 but may break down in the context of a pandemic disease with higher mortality and morbidity among the working-age population. We combine a review of the scientific literature with a review of news/media articles to characterize causal pathways and identify potential research gaps. Where possible, we identify processes that are unique to less developed countries and processes that interact with preexisting social inequities in the United States. We conclude with a summary of urgent needs for FEW-health modeling to improve decision-making for future viral pandemics.

\section{METHODS}

We conducted a scoping review of the peer-reviewed literature for articles addressing food-energy-water phenomena in the context of COVID-19. A scoping review aims to quantify the nature and extent of available research without critical appraisal of research quality. ${ }^{43}$ Article abstracts of journals indexed in the Web of Science (WoS) Core Collection ${ }^{44}$ were queried on October 15, 2020 using a syntax that allows for diverse words to qualify as food, energy, or water concepts. This syntax is summarized in Supporting Information (SI) Table S1. The search was confined to publications in 2019 and 2020. We consider it very likely that virtually all articles that focused on food/energy/water interactions in any substantive way in the context of COVID-19 would have used one of the relevant terms in the abstract.

The search returned 179 articles, which were screened manually for relevance. A total of 98 articles were excluded without further review based on the conditions summarized in SI Table S2. The remaining 81 articles were reviewed to extract causal associations asserted or evaluated by authors. SI Table S3 lists all articles returned by the WoS search and excluded (sorted by exclusion reason). SI Table S4 summarizes all articles retained from the WoS search.

Article abstracts were reviewed for assertions about causal relationships. These relationships were recorded by authors (M.J., R.C., and R.H.) and research assistants (G.B. and M.M.). Author R.C. reviewed all coding and consolidated similar concepts using consistent terminology. Causal associations were combined using general terminology to avoid exponential proliferation of causal relationships appearing in a graphical model. Author R.C. synthesized all articles using R. ${ }^{45}$ This method was used successfully on a larger scale by Calder et al. $^{46}$

We note that the scientific literature is rapidly evolving, and so our mapping of literature coverage and gaps is subject to ongoing reevaluation. We also note that we have focused on cross-sector FEW nexus relationships rather than intrasector phenomena, where systems thinking is also needed. ${ }^{47}$

We undertook a complementary review of news/media articles to evaluate which food-energy-water concepts are being addressed in connection with COVID-19 outside the peer-reviewed literature. This was done to identify possible gaps between issues of popular interest and the concepts addressed by existing research. This is particularly important due to the rapid nature of evolving COVID-19 and the less rapid pace of academic peer review and publishing.

Using the Nexis Uni database, ${ }^{48}$ we extracted news/media articles including in their titles at least two of the three nexus concepts: food + energy (FE), food + water (FW), or energy + water $(\mathrm{EW})$. Article types include press releases and newspaper articles. The distribution of article types is presented in SI Figure S1. The words retained to describe each of the food, energy, and water concepts are the same as those summarized in the WoS search (SI Table S1, rows 3-5). We confined our search to articles with these terms appearing in the title in order to generate a manageable number of results. Searching in article texts returns more than 1.4 million articles of which most are irrelevant (from a cursory screening). Final and rejected search syntaxes are described in SI Table S5. News/ media searches were performed on October 4, 2020 and 
returned 572 total results, split between FW (184), EW (185), and FE (203). No articles included food, energy, and water together in their titles.

All authors and research assistant C.G. then coded causal relationships asserted in news/media articles as was done for the WoS search. Given the large number of news/media articles returned, we manually reviewed a subset of $25 \%$ each of FW, EW, and FE. The $25 \%$ reviewed for each category were the first $25 \%$ as sorted by Nexis Uni in decreasing order of relevance; cursory review of the remaining $75 \%$ of articles in each group coded revealed that the majority presented no discernible link to food-energy-water systems and/or included only a tangential reference to COVID-19. Duplicate articles (approximately 22\%) were skipped. Roughly 52\% of articles were market reports that mentioned COVID-19 that did not make any causal claims.

For all 572 news/media results, we evaluated the distribution of articles by industry and by article type and performed word frequency analysis for each nexus group (EW, FE, and FW). Word frequency analysis is often used as a screening method to identify concepts or associations of particular concern within a large body of literature. ${ }^{49}$ This analysis was carried out using the WordCloud package ${ }^{50}$ in Python. ${ }^{51}$

Finally, for all 572 news/media results, we investigated distributional similarity measures for a subset of highfrequency words to better understand their contextual significance in news/media articles. The distributional similarity measures the number of contexts shared by words in a given text under the assumption that words that occur in similar contexts have similar meanings. ${ }^{52,53}$ This analysis was carried out using the NLTK package for Python. ${ }^{54}$

We note that our findings are based on articles written in English and therefore may not capture phenomena occurring only in non-English-speaking countries. However, we are not aware of FEW/COVID-19 phenomena unique to the nonEnglish-speaking world.

\section{RESULTS AND DISCUSSION}

Supply-Side Stresses. The most frequently identified relationships correspond to risks associated with work in the food sector (notably meatpacking and processing); food sector workers are at high risk of SARS-CoV-2 infection, posing a risk of worker illness and mortality and necessitating physical distancing interventions, all of which have disrupted a food system dependent on labor inputs. This has resulted in localized food shortages with unclear impacts on nutrition and health. ${ }^{55}$ All relationships identified in scientific and news/ media articles relevant to supply-side disruptions in FEW sectors are displayed in Table 1. All causal relations identified are listed in SI Table S6 along with summary statistics and citation information.

In the United States, black, Hispanic, and Native American individuals face disproportionate COVID-19 risks, partly as a result of food, energy, and water systems. They are highly represented in workplaces with higher COVID-19 risks such as meatpacking ${ }^{56,57}$ and are also more likely to be food-insecure and hence vulnerable to disrupted food supply chains. ${ }^{58}$ Meanwhile, food insecurity contributes to higher rates of preexisting health conditions, which in turn increases susceptibility to COVID-19 morbidity and mortality. ${ }^{59}$ These system dynamics are represented in Figure 1 and explored further below.
Table 1. FEW Supply-Side Relationships Asserted in Scientific and News/Media Articles

\begin{tabular}{|c|c|c|}
\hline \multirow[b]{2}{*}{ relationship } & \multicolumn{2}{|c|}{ percent reporting $^{a}$} \\
\hline & $\begin{array}{c}\text { scientific } \\
\text { articles }\end{array}$ & $\begin{array}{l}\text { news/media } \\
\text { articles }\end{array}$ \\
\hline $\begin{array}{l}\text { economic support } \rightarrow \text { purchasing power (of } \\
\text { producers) }\end{array}$ & $22 \%$ & $16 \%$ \\
\hline $\begin{array}{l}\text { food supply } \rightarrow \text { food/nutritional security/ } \\
\text { choices }\end{array}$ & $6 \%$ & $20 \%$ \\
\hline physical distancing $\rightarrow$ food supply ${ }^{b}$ & $9 \%$ & $16 \%$ \\
\hline food supply $\rightarrow$ SARS-CoV-2 transmission ${ }^{c}$ & $9 \%$ & $9 \%$ \\
\hline water availability $\rightarrow$ food supply & $2 \%$ & $9 \%$ \\
\hline SARS-CoV-2 transmission $\rightarrow$ food supply ${ }^{d}$ & $4 \%$ & $4 \%$ \\
\hline physical distancing $\rightarrow$ water quality ${ }^{e}$ & $4 \%$ & 0 \\
\hline $\begin{array}{l}\text { employment/economic activity } \rightarrow \text { water } \\
\text { quality }\end{array}$ & $4 \%$ & 0 \\
\hline water availability $\rightarrow$ water security & 0 & $1 \%$ \\
\hline
\end{tabular}

a"Percent reporting" reflects articles discussing supply-side and demand-side effects. ${ }^{b}$ Physical distancing measures instituted in meat processing and packing plants and elsewhere have resulted in food supply slowdowns. ${ }^{c}$ Meat processing and packing plants are high-risk occupational settings for COVID-19, and there have been many outbreaks there. ${ }^{d}$ COVID-19 outbreaks in meat processing and packing plants and elsewhere lead to absenteeism, slowing down food production. ${ }^{e}$ Increased occupancy of residential buildings as a result of workplace distancing have changed volumes and quantities of wastewater produced worldwide. ${ }^{f}$ Diminished industrial production at the start of the pandemic has changed volumes and quantities of wastewater produced worldwide.

The only cross-sector, supply-side stress identified was the potential impact of water availability on food production. This is consistent with recent observations that, generally, energy systems have weathered COVID-19 with no major disruptions, likely due to the overall suppressive effect the pandemic has had on energy demand (discussed in the Demand-Side Stresses section). ${ }^{26}$

Economic support to agricultural producers was widely discussed, particularly in the U.S. media (between April 2020 and March 2021, roughly $\$ 42$ billion in public funds was appropriated to support the U.S. food sector).$^{60-62}$ However, we did not identify any articles (news/media or scientific) evaluating whether enhanced producer purchasing power affects overall food supply or food security. Supply-side economic support has also generally not translated into support for food workers (e.g., paid sick leave) who are disproportionately susceptible to occupational SARS-CoV-2 exposure, which in turn destabilizes food supplies. ${ }^{63-65}$

The news/media review identified 50 food-energy, 63 food-water, and 129 energy-water articles classified under "Energy \& Utilities" (SI Figure S1). Word frequency analysis (SI Figure S2) also revealed a strong industry focus in EW articles ("market" and related words most represented) compared to the consumer focus among FE and FW articles ("COVID," "people," and related words most represented). This is also reflected in the results of semantic distribution analysis undertaken for the terms "government" (highly represented in FE and FW articles, SI Table S7) and "market" (highly represented in EW articles, SI Table S8). Many industry-related terms (e.g., "market," "vendors," "forecast," "order") appeared frequently in a similar context as the term "government," supporting our finding that EW articles, more than FE and FW articles, focused on challenges, perceptions, and concerns of producers and industries. It was therefore 


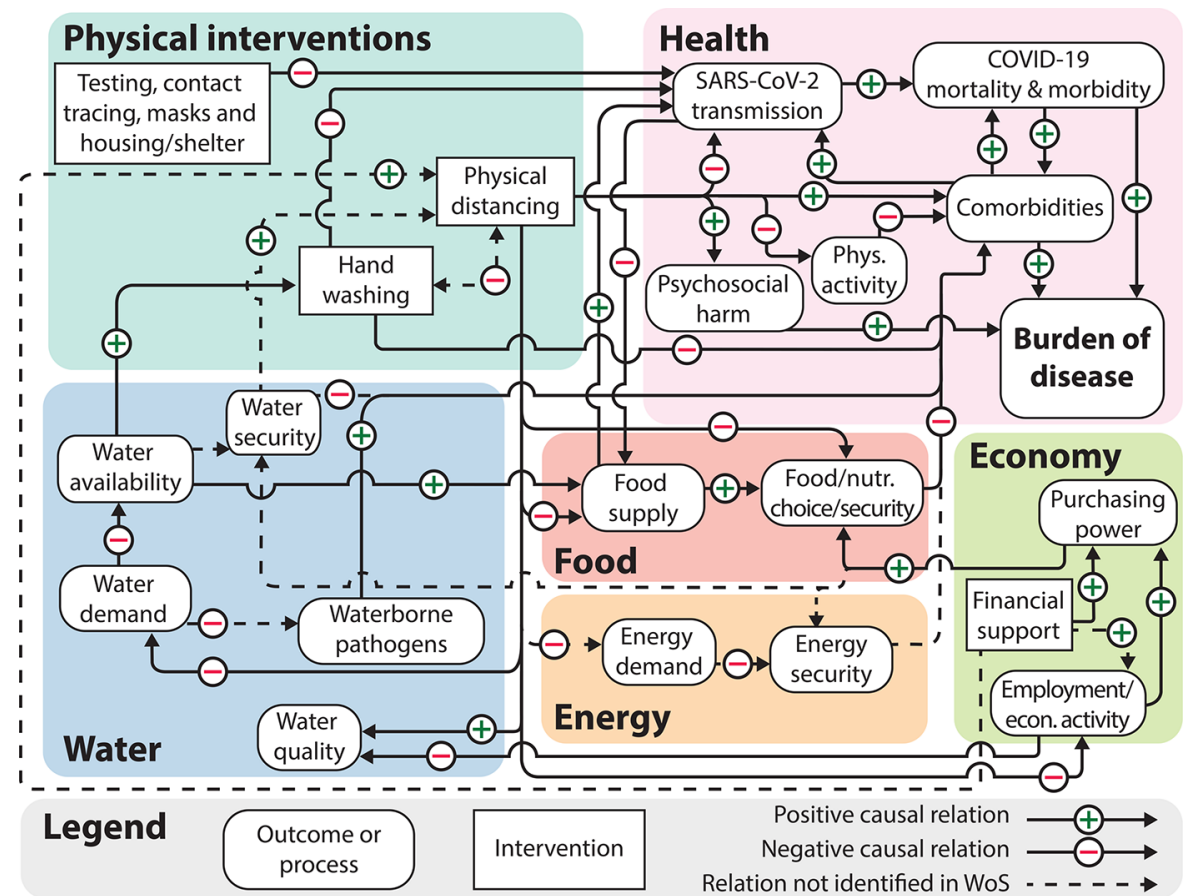

Figure 1. Relations among food, energy, water, health, and economic concepts in the context of COVID-19. Hatched lines are relations not corroborated in a Web of Science (WoS) search and correspond to possible research gaps. All hatched lines correspond to results of the news/ media review except energy demand $\rightarrow$ energy security (limited media predictions not found by news/media review) and energy security $\rightarrow$ comorbidities (logical inference and media reports that emerged after our formal search). Non-FEW relations occurring only once in scientific articles are omitted for clarity. A complete list of relations with journal citation information and summary statistics for a news/media search included in SI Table S6. Positive/negative associations refer to expected numerical relationships rather than better/worse judgments.

surprising that no FE or EW cross-sector, supply-side relationships were identified from the news/media review.

Close inspection of the energy-water articles however reveals that virtually all are either market reports for crosssector products (e.g., water heaters) or discuss industry concern about cross-sector trade-offs on the demand side. This includes water and power disconnections and disconnection bans introduced during the pandemic as described in the Demand-Side Stresses section. While supply-side terminology was heavily represented in news/media articles returned by the EW search, the underlying stresses fell virtually exclusively on the demand side.

After our structured searches were completed, in February 2021, a cold wave struck North America. This caused power failures in Texas where the electrical grid depends on poorly winterized generating assets and lacks regional interconnections. $^{66}$ This imperiled COVID-19 outpatients dependent on portable oxygen concentrators ${ }^{67}$ and forced people in unheated homes to weigh risks of cold exposure against risks of contracting SARS-CoV-2 in congregate shelters. ${ }^{68}$ This demonstrates a causal connection between energy security and COVID-19 morbidity and mortality not uncovered in our formal search.

Demand-Side Stresses. The most widely discussed demand-side stresses on FEW security relate to a collapse in purchasing power among lower-income individuals dependent on income from the retail, hospitality, and food services sectors. These sectors were severely affected by physical distancing interventions such as bar and restaurant closures. In the U.S., these disruptions disproportionately affected women and black, Hispanic, and Native American people. ${ }^{57,69}$
Economic impacts from COVID-19 and related interventions have created FEW insecurities on the demand side (summarized in Table 2). In the United States, a patchwork of energy and water disconnection moratoria has so far reduced the number of utility disconnections thus representing a type of economic support by utilities to consumers. ${ }^{70}$ With energy arrearages by the end of 2020 totaling roughly $\$ 32$ billion in the U.S. alone and disconnection moratoria now expiring, ${ }^{27}$ a utilities access crisis may have been delayed rather than avoided.

Lower income and/or black, Hispanic, or Native American households are also at higher risks of illness and death from COVID-19. (The Supply-Side Stresses section discusses this in the setting of FEW.) However, we did not identify articles linking COVID-19 morbidity or mortality to FEW disruptions, apart from supply-side impacts on food workers described earlier.

Racial disparities in economic security translate to racial disparities in FEW security during the COVID-19 pandemic. For example, in the U.S., food insecurity increased from roughly $19 \%$ to $32 \%$ among white households and from $39 \%$ to $50 \%$ among black households. ${ }^{58}$ Even controlling for economic security, racial disparities in FEW security persist. For example, in a nationally representative sample of households within $200 \%$ of the federal poverty line, black households had 3 times the odds of having been disconnected from power in the month to May 2020, while households under $100 \%$ of the poverty line had no increased odds compared to the study population as a whole. ${ }^{71}$

Physical distancing measures implemented in response to COVID-19 vastly increased person-hours spent in residential neighborhoods, changing food, energy, and water demand 
Table 2. FEW Demand-Side Relationships Asserted in Scientific and News/Media Articles

\begin{tabular}{|c|c|c|}
\hline \multirow[b]{2}{*}{ relationship } & \multicolumn{2}{|c|}{ percent reporting $^{a}$} \\
\hline & $\begin{array}{l}\text { scientific } \\
\text { articles }\end{array}$ & $\begin{array}{l}\text { news/media } \\
\text { articles }\end{array}$ \\
\hline $\begin{array}{l}\text { economic support } \rightarrow \text { purchasing power (of } \\
\text { consumers) }\end{array}$ & $22 \%$ & $16 \%$ \\
\hline $\begin{array}{l}\text { physical distancing } \rightarrow \text { employment/ } \\
\text { economic activity }\end{array}$ & $10 \%$ & $25 \%$ \\
\hline $\begin{array}{l}\text { purchasing power } \rightarrow \text { food/nutrition } \\
\text { security/choices }\end{array}$ & $9 \%$ & $25 \%$ \\
\hline $\begin{array}{l}\text { food supply } \rightarrow \text { food/nutrition security/ } \\
\text { choices }\end{array}$ & $6 \%$ & $20 \%$ \\
\hline physical distancing $\rightarrow$ food supply ${ }^{c}$ & $9 \%$ & $16 \%$ \\
\hline purchasing power $\rightarrow$ water security & 0 & $17 \%$ \\
\hline purchasing power $\rightarrow$ energy security & 0 & $12 \%$ \\
\hline $\begin{array}{l}\text { employment/economic activity } \rightarrow \\
\text { purchasing power }\end{array}$ & $5 \%$ & $6 \%$ \\
\hline economic support $\rightarrow$ physical distancing $^{d}$ & 0 & $6 \%$ \\
\hline physical distancing $\rightarrow$ water demand ${ }^{e}$ & $4 \%$ & $4 \%$ \\
\hline $\begin{array}{l}\text { physical distancing } \rightarrow \text { food/security } \\
\text { nutrition/choices }\end{array}$ & $4 \%$ & 0 \\
\hline water security $\rightarrow$ physical distancing ${ }^{g}$ & 0 & $4 \%$ \\
\hline water demand $\rightarrow$ waterborne pathogens ${ }^{h}$ & 0 & $2 \%$ \\
\hline physical distancing $\rightarrow$ energy demand ${ }^{i}$ & 0 & $1 \%$ \\
\hline physical distancing $\rightarrow$ hand washing ${ }^{j}$ & 0 & $1 \%$ \\
\hline
\end{tabular}

a"Percent reporting" reflects articles discussing supply-side and demand-side effects. ${ }^{b}$ Physical distancing measures heavily disrupted certain economic sectors such as hospitality and tourism leading to unemployment and economic precarity. ${ }^{c}$ Decreased patronage of restaurants and other congregate dining settings (and increased athome cooking) led to a mismatch in food packaging size supply vs demand. ${ }^{d}$ Enhanced unemployment and other benefits make economically disruptive public health policies more feasible. ${ }^{e}$ Decreased industrial/commercial building occupancy and increased residential building occupancy changes the volume and timing of water demand. ${ }^{f}$ Decreased patronage of restaurants and other congregate dining settings (and increased at-home cooking) led to changes in food choices. ${ }^{g}$ Lack of household drinking water access (e.g., in less developed countries) requires congregation around community spigots and impeding physical distancing ${ }^{h}$ Standing water in the plumbing of commercial/industrial/institutional facilities with reduced occupancy can promote the proliferation of legionella. ${ }^{i}$ Decreased industrial/commercial building occupancy and increased residential building occupancy changes the volume and timing of energy demand. ${ }^{j}$ Physical distancing imperatives reduce the feasibility of hand washing in settings with community spigots (e.g., in less developed countries)

patterns. Electrical grid failures were widely prophesied for summer 2020 given the sharp increase in remote work during the COVID-19 pandemic, $^{72,73}$ but we did not find evidence that this had occurred as of June 2021. In less developed countries where distributed drinking water access is not universal and water shortages are common, news/media articles suggested a trade-off between routine hand washing and physical distancing ${ }^{74}$ and difficulty of following hand washing advice while leaving water available for other uses. ${ }^{75}$ We did not identify scientific articles characterizing the physical distancing/hand-washing trade-off or evaluating competing demands for water use in the context of minimizing the burden of disease.

A smaller number of news/media and scientific articles addressed other demand-side disruptions to FEW systems not directly associated with purchasing power. This includes packaging size supply-demand mismatches (associated with the collapse in retail dining), which has led to substantial wastage of food as represented in Table 2 by physical distancing $\rightarrow$ food supply. ${ }^{76}$ The second-order impacts of food waste on energy and water waste are increasingly appreciated, but papers returned by our review did not address this. ${ }^{77} \mathrm{We}$ are aware of reports of legionella proliferating in stagnant water in pipes and tanks of buildings shut down following physical distancing orders. ${ }^{78}$ This is particularly concerning given the risks associated with SARS-CoV-2/legionella coinfection. ${ }^{79}$ However, our review did not capture any scientific articles that addressed these phenomena.

FEW/COVID-19 System Dynamics. COVID-19 and associated policy interventions like physical distancing have had profound and uneven impacts on human health. Many of these impacts have been realized through intermediate effects on FEW systems as described above. Aggregating these causal relationships uncovers feedback loops and trade-offs that span traditional areas of research and practice. Below, we discuss these system dynamics. Figure 1 presents our integrated conceptual model of FEW/COVID-19 interactions. (All causal relations identified are listed in SI Table S6 along with summary statistics; FEW supply- and demand-side relations summarized in Tables 1 and 2 above.)

First, SARS-CoV-2 spreads throughout the population as a function of social and virological parameters. Morbidity and mortality are determined by many variables including nutritional status and food security. ${ }^{80}$ The conditions of meatpacking and food processing plants promote disease spread, but these facilities are essential components of the food supply chain. ${ }^{81}$ Outbreaks there create disease burden among workers and among people who may suffer from supply chain disruptions resulting from worker absenteeism. Physical distancing (e.g., shift reductions) reduces the expected burden of disease among workers but may exacerbate food insecurities in the general population. This represents a direct burden of disease from malnutrition and indirect burden of disease from increased vulnerability to viral disease. There is currently no quantitative decision support for these interacting foodhealth-virus processes.

Second, economic disruption from COVID-19 (loss of wages among the sick) or policy responses (closure of industries such as retail dining) leads to the burden of disease via FEW insecurities and psychosocial impacts (described in the Demand-Side Stresses section). Physical distancing reduces disease burden, particularly among groups with high casefatality rates. However, these groups are older and bear fewer of the countervailing economic impacts or second-order FEW insecurity risks. This raises equity issues that have been widely interrogated in the popular press but of which there has been virtually no quantitative analysis. Immediate and long-term impacts of simultaneous food, energy, and water affordability crises among low-income families are also unknown.

Third, food supply (and much else) depends on water and energy inputs, while food, energy, and water supply all depend on labor and capital inputs. COVID-19 morbidity and mortality has been concentrated among older people rather than working-age adults, ${ }^{82}$ and large-scale supply-side FEW system breakdowns have so far been avoided. In the context of COVID-19, decision makers have therefore not had to confront trade-offs that might be forced by a pandemic driven by a deadlier pathogen such as the $1918 \mathrm{H} 1 \mathrm{~N} 1$ strain. A pandemic that kills or disables a substantial fraction of FEW workers would force decision makers to weigh provision of 
Table 3. Pathways Longer than Two Relationships in Series Identified by Articles from WoS Search

\begin{tabular}{|c|c|c|}
\hline pathway & narrative explanation & citations \\
\hline $\begin{array}{l}\text { food supply } \rightarrow \text { SARS-CoV-2 transmission } \rightarrow \text { food/nutrition choices/security } \\
\quad \rightarrow \text { environment }{ }^{a}\end{array}$ & $\begin{array}{l}\text { the perception of certain foods as vectors for SARS-CoV-2 may lead } \\
\text { to more sustainable food choices }\end{array}$ & Yang $^{90}$ \\
\hline physical distancing $\rightarrow$ employment $\rightarrow$ purchasing power & $\begin{array}{l}\text { physical distancing can create economic precarity by reducing } \\
\text { opportunities for certain types of work (e.g., food supply chain) }\end{array}$ & Orden $^{91}$ \\
\hline $\begin{array}{l}\text { physical distancing } \rightarrow \text { food supply } \rightarrow \text { food/nutrition choices/security } \rightarrow \\
\text { comorbidities }\end{array}$ & $\begin{array}{l}\text { physical distancing has second-order effects on health through } \\
\text { reduced food security }\end{array}$ & $\begin{array}{l}\text { Akseer et } \\
\text { al. }^{92}, \mathrm{Lal}^{93}\end{array}$ \\
\hline $\begin{array}{l}\text { water availability } \rightarrow \text { food supply } \rightarrow \text { food/nutrition choices/security } \rightarrow \\
\text { comorbidities } \rightarrow \text { COVID-19 mortality and morbidity }\end{array}$ & $\begin{array}{l}\text { water availability has second-order effects on health through reduced } \\
\text { food security }\end{array}$ & Woertz $^{94}$ \\
\hline $\begin{array}{l}\text { SARS-CoV- } 2 \text { transmission } \rightarrow \text { COVID-19 mortality and morbidity } \rightarrow \\
\text { comorbidities } \rightarrow \text { burden of disease }\end{array}$ & $\begin{array}{l}\text { without intervention, COVID-19 will leave long-term impacts on } \\
\text { maternal and general health }\end{array}$ & $\begin{array}{l}\text { Kapur and } \\
\operatorname{Hod}^{95}\end{array}$ \\
\hline comorbidities $\rightarrow$ COVID-19 mortality and morbidity $\rightarrow$ burden of disease & comorbidities exacerbate COVID-19 & $\begin{array}{l}\text { Gasmi et } \\
\text { al. }^{96}\end{array}$ \\
\hline
\end{tabular}

${ }^{a}$ Yang ${ }^{90}$ quantified impacts on food choices in the context of broadly defined environmental "sustainability" but specific environmental end points were outside the scope of their study.

essential services against risks to workers, where risks to workers would also jeopardize the provision of essential services. Meanwhile, COVID-19 has revealed the lack of modeling tools available to predict the impact of capital or labor shortfalls on integrated FEW systems including risks of cascading FEW crises.

The current evidence base does not facilitate analysis of these feedbacks and trade-offs. Almost all articles coded considered one-way relationships between at most two concepts in series (i.e., $\mathrm{A} \rightarrow \mathrm{B}$ and $\mathrm{C} \rightarrow \mathrm{D}$ but not $\mathrm{B} \rightarrow$ C). Despite the complexity of coupled human-natural systems, most evidence in environmental and social sciences accounts only for such one-way interactions, limiting the ability of policymakers and others to quantify trade-offs and interactions across sectors. ${ }^{46}$ This contrasts markedly to the biomedical sciences where careful statistical analysis is applied to determine the role of environmental exposures and prior disease status on mortality, ${ }^{83-87}$ the impact of COVID-19 on comorbidities, and the possible confounding role of treatment for comorbidities on COVID-19 outcomes. ${ }^{889}$

While the study of complex causal structures in the FEW sciences has been limited, we did identify six pathways in the literature that reflect interest in second-order impacts, unintended consequences, and system dynamics (see Table 3 for narrative descriptions). Of 81 scientific articles reviewed, 18 evaluated or asserted multiple outcomes from a given intervention or variable (e.g., impacts of physical distancing on nutrition, physical activity, etc.) or, conversely, multiple predictors of a given outcome (e.g., impacts of hand washing and physical distancing on SARS-CoV-2 transmission). This framing allows for analysis of trade-offs and comparative efficacy of alternative interventions. However, no article that we identified explicitly undertook such an analysis.

Overall, COVID-19 has exposed trade-offs and feedbacks around FEW systems stressed by viral pandemics, but these dynamics have not yet been well characterized. Because most working-age people who contract SARS-CoV-2/COVID-19 recover, direct impacts on the supply-side FEW systems have been smaller than demand-side impacts of COVID-19 policy responses instituted to protect vulnerable populations (e.g., physical distancing). FEW systems have therefore withstood a number of stresses posed by COVID-19, such as the impact of virus morbidity and mortality on labor inputs, even as COVID19 has highlighted these vulnerabilities.

Research Needs. The FEW nexus has amplified SARSCoV-2/COVID-19 spread (e.g., initial outbreak and spread among food sector workers) and has been destabilized by the loss of labor and capital inputs. While widespread food shortages, blackouts, and water shortages have largely been avoided, COVID-19 has demonstrated that FEW models have overlooked purchasing power and labor inputs as factors in assessing system resiliency. Similarly, tools to forecast viral spread across a population do not generally consider how illness and death from viruses contrast with (or interact with) burden of disease introduced by physical distancing measures, particularly among groups with low case-fatality rates. These impacts may be direct (psychosocial impacts) or triggered by FEW perturbations on the supply side (loss of labor inputs to ensure FEW system resiliency) or the demand side (loss of purchasing power to ensure FEW security).

Virtually all research we identified was retrospective, reporting on stresses that had already occurred. Overall, there is a lack of exploratory research including scenario analysis, risk analysis, and numerical simulation of FEW systems. Without these methods, insights into the potential for cascading failures will be limited. For example, as of July 2021, we have avoided large-scale supply-side breakdowns such as utility failures, despite the acknowledged potential of such events. $^{72,73}$ We did not identify any research pointing to the conditions (virological or meteorological parameters, etc.) that would lead to such breakdowns, limiting the ability for resiliency planning.

Water stresses in less developed countries have been acknowledged as a constraint on the feasibility of widespread handwashing, potentially increasing COVID-19 risks. ${ }^{97,98}$ As of July 2021, inhalation of droplets and aerosols is now understood to drive SARS-CoV-2 transmission, ${ }^{99,100}$ reducing the urgency of this constraint. However, hands/fomite transmission may be more important in future pandemics, and we did not identify any quantitative framework to understand how pandemics may change optimal water allocation in densely populated, water-stressed areas.

Recent history has demonstrated that pandemics of greater severity than COVID-19 (e.g., the 1918-1920 H1N1 pandemic) are very possible. ${ }^{101,102}$ Major supply-side FEW disruptions were avoided during COVID-19, likely due to relatively low mortality among working-age adults. For example, in the United States, the case fatality rate of COVID-19 was roughly 130 times lower among 18-to-29year-olds than among 65-to-74-year-olds prior to widespread vaccination. ${ }^{82}$ Across the three waves of the $1918-1920$ H1N1 pandemic, this was almost exactly reversed with excess deaths among 15-to-44-year-olds 129 times higher than among $\geq 65$ year-olds. ${ }^{101}$ Likewise, MERS-CoV and SARS-CoV-1 have case 
fatality rates of roughly $34 \%$ and $9.5 \%$, respectively, compared to $\sim 1 \%$ with SARS-CoV-2. ${ }^{103}$ Future risk and resilience simulations developed to enhance preparedness must account for such possibilities.

Quantitative risk trade-off frameworks can improve decisionmaking even when underlying processes are subject to large uncertainties. ${ }^{104,105}$ These approaches are increasingly appreciated as tools to structure complex policy questions ${ }^{106}$ and would likely be a useful approach for FEW resiliency planning. It is essential that such characterizations leverage the existing simulation capacity of the supply side of food-energy-water systems. ${ }^{107}$

\section{ASSOCIATED CONTENT}

\section{SI Supporting Information}

The Supporting Information is available free of charge at https://pubs.acs.org/doi/10.1021/acs.estlett.1c00291.

Web of Science search syntax and annotated results for scientific literature review, NexisUni search syntaxes, summary statistics and summary figures for news/media review (PDF)

\section{AUTHOR INFORMATION}

\section{Corresponding Author}

Ryan S. D. Calder - Department of Population Health Sciences and Global Change Center, Virginia Tech, Blacksburg, Virginia 24061, United States; Faculty of Health Sciences, Virginia Tech, Roanoke, Virginia 24016, United States; Department of Civil and Environmental Engineering, Duke University, Durham, North Carolina 27708, United States; orcid.org/0000-0001-5618-9840; Phone: (540) 231-2430; Email: rsdc@vt.edu; Fax: (540) 231-7007

\section{Authors}

Caitlin Grady - Department of Civil and Environmental Engineering and Rock Ethics Institute, Pennsylvania State University, University Park, Pennsylvania 16802, United States

Marc Jeuland - Sanford School of Public Policy and Global Health Institute, Duke University, Durham, North Carolina 27708, United States; RWI-Leibniz Institute for Economic Research, 45128 Essen, Germany

Christine J. Kirchhoff - Department of Civil and Environmental Engineering, University of Connecticut, Storrs, Connecticut 06269, United States

Rebecca L. Hale - Department of Biological Sciences, Idaho State University, Pocatello, Idaho 83209, United States

Rebecca L. Muenich - School of Sustainable Engineering and the Built Environment, Arizona State University, Tempe, Arizona 85281, United States; 이이.org/0000-00019920-9346

Complete contact information is available at:

https://pubs.acs.org/10.1021/acs.estlett.1c00291

\section{Notes}

The authors declare no competing financial interest.

\section{ACKNOWLEDGMENTS}

This work was inFEWsed with support from the National Socio-Environmental Synthesis Center (SESYNC) under funding received from the National Science Foundation DBI1639145. The authors acknowledge the support of SESYNC collaborators Jeffrey Bielicki and Douglas Jackson Smith (Ohio State U.), Morey Burnham (Idaho State U.), Bryce Hannibal (Utah State U.), Shamitha Keerthi (The Nature Conservancy), Carsten Prasse (Johns Hopkins U.), Ashlynn Stillwell (U. Illinois), and Brian Thiede (Penn State U.). We thank research assistants Guillaume Bouchard (Harvard U.), Chloe Gaylor (Virginia Tech), and Michelle Moffa (Duke U.) for their help with the literature review.

\section{REFERENCES}

(1) Volpato, G.; Fontefrancesco, M. F.; Gruppuso, P.; Zocchi, D. M.; Pieroni, A. Baby pangolins on my plate: possible lessons to learn from the COVID-19 pandemic. J. Ethnobiol. Ethnomed. 2020, 16 (1), 19.

(2) Center for Systems Science and Engineering (CSSE), Johns Hopkins University, COVID-19 dashboard. https://coronavirus.jhu. edu/map.html (accessed July 7, 2021).

(3) United States Bureau of Economic Analysis (U.S. BEA), Gross domestic product, 2nd quarter 2020 (second estimate); corporate profits, 2nd quarter 2020 (preliminary estimate). https://www.bea. gov/data/gdp/gross-domestic-product (accessed Sep 18, 2020).

(4) Global Economic Effects of COVID-19; Report R46270, United States Congressional Research Service (U.S. CRS): Washington, DC, 2020.

(5) Greger, M. Industrial animal agriculture's role in the emergence and spread of disease. In The Meat Crisis: Developing More Sustainable Production and Consumption; D'Silva, J., Webster, J., Eds.; Earthscan LTD: London, UK, 2010; pp 161-172.

(6) Sheppard, S. K.; Guttman, D. S.; Fitzgerald, J. R. Population genomics of bacterial host adaptation. Nat. Rev. Genet. 2018, 19 (9), $549-565$

(7) von Borell, E. Neuroendocrine integration of stress and significance of stress for the performance of farm animals. Appl. Anim. Behav. Sci. 1995, 44 (2-4), 219-227.

(8) Xu, C.; Fan, W.; Wei, R.; Zhao, H. Isolation and identification of swine influenza recombinant $\mathrm{A} /$ Swine/Shandong/1/2003(H9N2) virus. Microbes Infect. 2004, 6 (10), 919-25.

(9) Brashares, J. S.; Arcese, P.; Sam, M. K.; Coppolillo, P. B.; Sinclair, A. R.; Balmford, A. Bushmeat hunting, wildlife declines, and fish supply in West Africa. Science 2004, 306 (5699), 1180-3.

(10) Guernier, V.; Hochberg, M. E.; Guegan, J. F. Ecology drives the worldwide distribution of human diseases. PLoS Biol. 2004, 2 (6), No. e141.

(11) Wilkie, D. S.; Starkey, M.; Abernethy, K.; Effa, E. N.; Telfer, P.; Godoy, R. Role of prices and wealth in consumer demand for bushmeat in Gabon, Central Africa. Conservation Biology 2005, 19 (1), 268-274.

(12) Greger, M. The Human/animal interface: emergence and resurgence of zoonotic infectious diseases. Crit. Rev. Microbiol. 2007, 33 (4), 243-99.

(13) Wolfe, N. D.; Dunavan, C. P.; Diamond, J. Origins of major human infectious diseases. Nature 2007, 447 (7142), 279-83.

(14) Woolhouse, M. E.; Gowtage-Sequeria, S. Host range and emerging and reemerging pathogens. Emerging Infect. Dis. 2005, 11 (12), 1842-7.

(15) Lewthwaite, P.; Wilkins, E. Natural history of HIV/AIDS. Medicine 2009, 37 (7), 333-337.

(16) United States Centers for Disease Control and Prevention (U.S. CDC), Basic statistics. HIV Basics. https://www.cdc.gov/hiv/ basics/statistics.html (accessed Sep 22, 2020).

(17) Breman, J. G.; Heymann, D. L.; Lloyd, G.; McCormick, J. B.; Miatudila, M.; Murphy, F. A.; Muyembe-Tamfun, J. J.; Piot, P.; Ruppol, J. F.; Sureau, P.; van der Groen, G.; Johnson, K. M. Discovery and description of Ebola Zaire virus in 1976 and relevance to the West African epidemic during 2013-2016. J. Infect. Dis. 2016, 214 (suppl 3), S93-S101.

(18) Mari Saez, A.; Weiss, S.; Nowak, K.; Lapeyre, V.; Zimmermann, F.; Dux, A.; Kuhl, H. S.; Kaba, M.; Regnaut, S.; Merkel, K.; Sachse, A.; Thiesen, U.; Villanyi, L.; Boesch, C.; Dabrowski, P. W.; Radonic, A.; 
Nitsche, A.; Leendertz, S. A.; Petterson, S.; Becker, S.; et al. Investigating the zoonotic origin of the West African Ebola epidemic. EMBO Mol. Med. 2015, 7 (1), 17-23.

(19) United States Centers for Disease Control and Prevention (U.S. CDC), 2014-2016 Ebola outbreak in West Africa. https:// www.cdc.gov/vhf/ebola/history/2014-2016-outbreak/index.html (accessed Sep 21, 2020).

(20) World Health Organization (WHO); Government of the Democratic Republic of the Congo, Ebolavirus disease in the DRC dashboard. https://who.maps.arcgis.com/apps/opsdashboard/index. html\#/e70c3804f6044652bc37cce7d8fcef6c (accessed Sep 22, 2020).

(21) Andersen, K. G.; Rambaut, A.; Lipkin, W. I.; Holmes, E. C.; Garry, R. F. The proximal origin of SARS-CoV-2. Nat. Med. 2020, 26 (4), 450-452.

(22) Wynants, L.; Van Calster, B.; Collins, G. S; Riley, R. D; Heinze, G.; Schuit, E.; Bonten, M. M J; Dahly, D. L; Damen, J. A; Debray, T. P A; de Jong, V. M T; De Vos, M.; Dhiman, P.; Haller, M. C; Harhay, M. O; Henckaerts, L.; Heus, P.; Kammer, M.; Kreuzberger, N.; Lohmann, A.; Luijken, K.; Ma, J.; Martin, G. P; McLernon, D. J; Andaur Navarro, C. L; Reitsma, J. B; Sergeant, J. C; Shi, C.; Skoetz, N.; Smits, L. J M; Snell, K. I E; Sperrin, M.; Spijker, R.; Steyerberg, E. W; Takada, T.; Tzoulaki, I.; van Kuijk, S. M J; van Bussel, B. C T; van der Horst, I. C C; van Royen, F. S; Verbakel, J. Y; Wallisch, C.; Wilkinson, J.; Wolff, R.; Hooft, L.; Moons, K. G M; van Smeden, M. Prediction models for diagnosis and prognosis of covid-19 infection: systematic review and critical appraisal. Brit. Med. J. 2020, 369, m1328.

(23) Czeisler, M. É.; Lane, R. I.; Petrosky, E.; Wiley, J. F.; Christensen, A.; Njai, R.; Weaver, M. D.; Robbins, R.; Facer-Childs, E. R.; Barger, L. K.; Czeisler, C. A.; Howard, M. E.; Rajaratnam, S. M. W. Mental health, substance use, and suicidal ideation during the COVID-19 pandemic - United States, June 24-30, 2020. MMWRMorbid. Mortal. W. 2020, 69 (32), 1049-1057.

(24) Daher, B. T.; Mohtar, R. H. Water-energy-food (WEF) Nexus Tool 2.0: guiding integrative resource planning and decisionmaking. Water Int. 2015, 40 (5-6), 748-771.

(25) World Economic Forum (WEF), The Water-food-energyclimate nexus: a facts and figures overview. In Water Security: The Water-Food-Energy-Climate Nexus, Waughray, D., Ed.; Island Press: Washington, DC, 2011.

(26) Al-Saidi, M.; Hussein, H. The water-energy-food nexus and COVID-19: towards a systematization of impacts and responses. Sci. Total Environ. 2021, 779, 146529.

(27) National Energy Assistance Directors' Association (NEADA) Jan. 28, 2021 letter to U.S. Congressional leaders. Washington, DC, 2021.

(28) Jones, K. E.; Patel, N. G.; Levy, M. A.; Storeygard, A.; Balk, D.; Gittleman, J. L.; Daszak, P. Global trends in emerging infectious diseases. Nature 2008, 451 (7181), 990-3.

(29) D’Odorico, P.; Davis, K. F.; Rosa, L.; Carr, J. A.; Chiarelli, D.; Dell'Angelo, J.; Gephart, J.; MacDonald, G. K.; Seekell, D. A.; Suweis, S.; Rulli, M. C. The Global food-energy-water nexus. Rev. Geophys. 2018, 56 (3), 456-531.

(30) Scanlon, B. R.; Ruddell, B. L.; Reed, P. M.; Hook, R. I.; Zheng, C.; Tidwell, V. C.; Siebert, S. The Food-energy-water nexus: transforming science for society. Water Resour. Res. 2017, 53 (5), 3550-3556.

(31) Bhowmick, G. D.; Dhar, D.; Nath, D.; Ghangrekar, M. M.; Banerjee, R.; Das, S.; Chatterjee, J., Coronavirus disease 2019 (COVID-19) outbreak: some serious consequences with urban and rural water cycle. npj Clean Water 2020, 3 (1), DOI: 10.1038/s41545020-0079-1.

(32) Cahill, N.; Morris, D. Recreational waters - a potential transmission route for SARS-CoV-2 to humans? Sci. Total Environ. 2020, 740, 140122.

(33) Nghiem, L. D.; Morgan, B.; Donner, E.; Short, M. D. The COVID-19 pandemic: considerations for the waste and wastewater services sector. Case Studies in Chemical and Environmental Engineering 2020, 1, 100006.
(34) Rimoldi, S. G.; Stefani, F.; Gigantiello, A.; Polesello, S.; Comandatore, F.; Mileto, D.; Maresca, M.; Longobardi, C.; Mancon, A.; Romeri, F.; Pagani, C.; Cappelli, F.; Roscioli, C.; Moja, L.; Gismondo, M. R.; Salerno, F. Presence and infectivity of SARS-CoV-2 virus in wastewaters and rivers. Sci. TotaOl Environ. 2020, 744, 140911.

(35) Albert, S.; Ruiz, A.; Peman, J.; Salavert, M.; Domingo-Calap, P., Lack of evidence for infectious SARS-CoV-2 in feces and sewage. Eur. J. Clin. Microbiol. Infect. Dis. 2021, DOI: 10.1007/s10096-021-043044.

(36) Ahmed, W.; Bibby, K.; D’Aoust, P. M.; Delatolla, R.; Gerba, C. P.; Haas, C. N.; Hamilton, K. A.; Hewitt, J.; Julian, T. R.; Kaya, D.; Monis, P.; Moulin, L.; Naughton, C.; Noble, R. T.; Shrestha, A.; Tiwari, A.; Simpson, S. L.; Wurtzer, S.; Bivins, A., Differentiating between the possibility and probability of SARS-CoV-2 transmission associated with wastewater: empirical evidence is needed to substantiate risk. FEMS Microbes 2021, 2, DOI: 10.1093/femsmc/ xtab007.

(37) Batlle-Bayer, L.; Aldaco, R.; Bala, A.; Puig, R.; Laso, J.; Margallo, M.; Vazquez-Rowe, I.; Anto, J. M.; Fullana-i-Palmer, P. Environmental and nutritional impacts of dietary changes in Spain during the COVID-19 lockdown. Sci. Total Environ. 2020, 748, 141410 .

(38) Aldaco, R.; Hoehn, D.; Laso, J.; Margallo, M.; Ruiz-Salmon, J.; Cristobal, J.; Kahhat, R.; Villanueva-Rey, P.; Bala, A.; Batlle-Bayer, L.; Fullana-i-Palmer, P.; Irabien, A.; Vazquez-Rowe, I. Food waste management during the COVID-19 outbreak: a holistic climate, economic and nutritional approach. Sci. Total Environ. 2020, 742, 140524.

(39) Zaneti, R. N.; Girardi, V.; Spilki, F. R.; Mena, K.; Westphalen, A. P. C.; da Costa Colares, E. R.; Pozzebon, A. G.; Etchepare, R. G. Quantitative microbial risk assessment of SARS-CoV-2 for workers in wastewater treatment plants. Sci. Total Environ. 2021, 754, 142163.

(40) Parks, C. A.; Nugent, N. B.; Fleischhacker, S. E.; Yaroch, A. L. Food system workers are the unexpected but under protected COVID heroes. J. Nutr. 2020, 150 (8), 2006-2008.

(41) Waltenburg, M. A.; Victoroff, T.; Rose, C. E.; Butterfield, M.; Jervis, R. H.; Fedak, K. M.; Gabel, J. A.; Feldpausch, A.; Dunne, E. M.; Austin, C.; et al. Update: COVID-19 among workers in meat and poultry processing facilities-United States, April-May 2020. MMWR-Morbid. Mortal. W. 2020, 69 (27), 887-892.

(42) Huff, A. G.; Beyeler, W. E.; Kelley, N. S.; McNitt, J. A. How resilient is the United States' food system to pandemics? J. Environ. Stud. Sci. 2015, 5 (3), 337-347.

(43) Grant, M. J.; Booth, A. A Typology of reviews: an analysis of 14 review types and associated methodologies. Health Info. Libr. J. 2009, 26 (2), 91-108.

(44) Clarivate, Web of Science Core Collection. https://clarivate. $\mathrm{com} /$ webofsciencegroup/solutions/web-of-science-core-collection/ (accessed Oct 1, 2020).

(45) $\mathrm{R}$ Core Team. $R$ v. 4.0.2; $\mathrm{R}$ Foundation for Statistical Computing: Vienna, Austria, 2020.

(46) Calder, R. S. D.; Alatorre, A.; Marx, R. S.; Mallampalli, V.; Mason, S. A.; Olander, L. P.; Jeuland, M.; Borsuk, M. E. Graphical models and the challenge of evidence-based practice in development and sustainability. Environ. Modell. Softw. 2020, 130, 104734.

(47) Naughton, C. C. Will the COVID-19 pandemic change waste generation and composition?: The need for more real-time waste management data and systems thinking. Resour. Conserv. Recycl. 2020, 162,105050 .

(48) LexisNexis, Nexis Uni. https://www.lexisnexis.com/en-us/ professional/academic/nexis-uni.page (accessed Sep 27, 2020).

(49) Cidell, J. Content clouds as exploratory qualitative data analysis. Area 2010, 42 (4), 514-523.

(50) Mueller, A. WordCloud for Python v. 1.8.1; New York, 2020.

(51) Python v. 3.9; Python Software Foundation: Wilmington, DE, 2020. 
(52) Harris, R. Contextual classification post-processing of Landsat data using a probabilistic relaxation model. Int. J. Remote Sens. 1985, 6 (6), 847-866.

(53) Rubenstein, H.; Goodenough, J. B. Contextual correlates of synonymy. Commun. ACM 1965, 8 (10), 627-633.

(54) Bird, S.; Loper, E. NLTK 3.5; NLTK Project: Melbourne, Australia, 2020.

(55) Laborde, D.; Martin, W.; Swinnen, J.; Vos, R. COVID-19 risks to global food security. Science 2020, 369 (6503), 500-502.

(56) Hawkins, D. Differential occupational risk for COVID-19 and other infection exposure according to race and ethnicity. Am. J. Ind. Med. 2020, 63 (9), 817-820.

(57) Feir, D.; Golding, C. Native employment during COVID-19: Hit hard in April but starting to rebound? Federal Reserve Bank of Minneapolis: Minneapolis, MN, 2020.

(58) Morales, D. X.; Morales, S. A.; Beltran, T. F., Racial/ethnic disparities in household food insecurity during the COVID-19 pandemic: a nationally representative study. J. Racial Ethn. Health Disparities 2020, Oct 14, pp 1-5 DOI: 10.1007/s40615-020-00892-7. (59) Belanger, M. J.; Hill, M. A.; Angelidi, A. M.; Dalamaga, M.; Sowers, J. R.; Mantzoros, C. S. Covid-19 and disparities in nutrition and obesity. N. Engl. J. Med. 2020, 383 (11), No. e69.

(60) United States Department of Agriculture (USDA), Fact sheet: United States Department of Agriculture provisions in H.R. 1319, the American Rescue Plan. https://www.usda.gov/media/press-releases/ 2021/03/10/fact-sheet-united-states-department-agricultureprovisions-hr-1319 (accessed Mar 15, 2020).

(61) United States Department of Agriculture (USDA), USDA announces coronavirus food assistance program. https://www.usda. gov/media/press-releases/2020/04/17/usda-announces-coronavirusfood-assistance-program (accessed Mar 1, 2020).

(62) United States Department of Agriculture (USDA), USDA to provide additional direct assistance to farmers and ranchers impacted by the coronavirus. https://www.usda.gov/media/press-releases/ 2020/09/18/usda-provide-additional-direct-assistance-farmers-andranchers (accessed Mar 1, 2020).

(63) COVID-19 and the impact on agriculture and food security; ILO Sectoral Brief, International Labour Organization (ILO): Geneva, Switzerland, 2020.

(64) Ghilarducci, T.; Farmand, A. Older workers on the COVID-19frontlines without paid sick leave. J. Aging Soc. Policy 2020, 32 (4-5), 471-476.

(65) Aday, S.; Aday, M. S. Impact of COVID-19 on the food supply chain. Food Quality and Safety 2020, 4 (4), 167-180.

(66) Krane, J.; Idel, R.; Volkmar, P. Winterization and the Texas Blackout: fail to prepare? Prepare to Fail; Rice University Baker Institute for Public Policy: Houston, TX, 2021.

(67) Hixenbaugh, M.; Trevizo, P. Texans recovering from COVID19 relied on machines to help them breathe. Then the power went out. The Texas Tribune, 2021.

(68) Merchant, N. Power failure: How a winter storm pushed Texas into crisis. Associated Press, 2021.

(69) Gangopadhyaya, A.; Waxman, E. Supporting Food Service and Preparation Workers during the COVID-19 Pandemic; The Urban Institute: Washington, DC, 2020.

(70) National Association of Regulatory Utility Commissioners (NARUC), Map of Disconnection Moratoria. https://www.naruc. org/compilation-of-covid-19-news-resources/map-of-disconnectionmoratoria/ (accessed Apr 5, 2021).

(71) Memmott, T.; Carley, S.; Graff, M.; Konisky, D. M. Sociodemographic disparities in energy insecurity among low-income households before and during the COVID-19 pandemic. Nat. Energy 2021, 6 (2), 186-193.

(72) Bredderman, W. Brace for blackouts in the summer of COVID19. The Daily Beast, 2020.

(73) Elsworthy, E. Why working from home could be a disaster for Australia's electricity grid this summer. $A B C$ News, 2020.

(74) Bhowmick, N. Handwashing helps stop COVID-19. But in India, water is scarce. National Geographic, 2020.
(75) Otto, B.; Kuzma, S.; Strong, C.; Chertock, M. Combating the Coronavirus Wthout Clean Water; World Resources Institute: Washington, DC, 2020.

(76) Felix, I.; Martin, A.; Mehta, V.; Mueller, C. US Food Supply Chain: Disruptions and Implications from COVID-19; McKinsey \& Company: Miami, FL, 2020.

(77) Marston, L. T.; Read, Q. D.; Brown, S. P.; Muth, M. K. Reducing water scarcity by reducing food loss and waste. Front. Sustain. Food Syst. 2021, 5, DOI: 10.3389/fsufs.2021.651476.

(78) Palazzolo, C.; Maffongelli, G.; D’Abramo, A.; Lepore, L.; Mariano, A.; Vulcano, A.; Bartoli, T. A.; Bevilacqua, N.; Giancola, M. L.; Di Rosa, E.; Nicastri, E., Legionella pneumonia: increased risk after COVID-19 lockdown? Italy, May to June 2020. Euro. Surveill. 2020, 25 (30), DOI: 10.2807/1560-7917.ES.2020.25.30.2001372.

(79) Dey, R.; Ashbolt, N. J. Legionella Infection during and after the COVID-19 Pandemic. ACS ES\&T Water 2021, 1 (1), 13-14.

(80) Fore, H. H.; Dongyu, Q.; Beasley, D. M.; Ghebreyesus, T. A. Child malnutrition and COVID-19: the time to act is now. Lancet 2020, 396 (10250), 517-518.

(81) Taylor, C. A.; Boulos, C.; Almond, D. Livestock plants and COVID-19 transmission. Proc. Natl. Acad. Sci. U. S. A. 2020, 117 (50), 31706-31715.

(82) United States Centers for Disease Control and Prevention (U.S. CDC), Risk for COVID-19 infection, hospitalization, and death by age group. https://www.cdc.gov/coronavirus/2019-ncov/coviddata/investigations-discovery/hospitalization-death-by-age.html (accessed Apr 8, 2021).

(83) Gu, T.; Mack, J. A.; Salvatore, M.; Sankar, S. P.; Valley, T. S.; Singh, K.; Nallamothu, B. K.; Kheterpal, S.; Lisabeth, L.; Fritsche, L. G.; Mukherjee, B. COVID-19 outcomes, risk factors and associations by race: a comprehensive analysis using electronic health records data in Michigan Medicine. medRxiv 2020, DOI: 10.1101/ 2020.06.16.20133140.

(84) Ji, H. L.; Zhao, R.; Matalon, S.; Matthay, M. A. Elevated plasmin(ogen) as a common risk factor for COVID-19 susceptibility. Physiol. Rev. 2020, 100 (3), 1065-1075.

(85) Sarmadi, M.; Moghanddam, V. K.; Dickerson, A. S.; Martelletti, L. Association of COVID-19 distribution with air quality, sociodemographic factors, and comorbidities: an ecological study of US states. Air Qual., Atmos. Health 2021, 14, 455.

(86) Sorci, G.; Faivre, B.; Morand, S. Explaining among-country variation in COVID-19 case fatality rate. Sci. Rep. 2020, 10 (1), 18909.

(87) Ssentongo, P.; Ssentongo, A. E.; Heilbrunn, E. S.; Ba, D. M.; Chinchilli, V. M. Association of cardiovascular disease and 10 other pre-existing comorbidities with COVID-19 mortality: A systematic review and meta-analysis. PLoS One 2020, 15 (8), No. e0238215.

(88) Gold, M. S.; Sehayek, D.; Gabrielli, S.; Zhang, X.; McCusker, C.; Ben-Shoshan, M. COVID-19 and comorbidities: a systematic review and meta-analysis. Postgrad. Med. 2020, 132 (8), 749-755.

(89) Jakhmola, S.; Indari, O.; Baral, B.; Kashyap, D.; Varshney, N.; Das, A.; Chatterjee, S.; Jha, H. C. Comorbidity assessment is essential during COVID-19 treatment. Front. Physiol. 2020, 11, 984.

(90) Yang, X. Potential consequences of COVID-19 for sustainable meat consumption: the role of food safety concerns and responsibility attributions. Br. Food J. 2020, 123, 455.

(91) Orden, D. Resilience and vulnerabilities of the North American food system during the COVID-19 pandemic. EuroChoices 2020, 19, 13.

(92) Akseer, N.; Kandru, G.; Keats, E. C.; Bhutta, Z. A. COVID-19 pandemic and mitigation strategies: implications for maternal and child health and nutrition. Am. J. Clin. Nutr. 2020, 112 (2), 251-256.

(93) Lal, R. Home gardening and urban agriculture for advancing food and nutritional security in response to the COVID-19 pandemic. Food Secur. 2020, 12, 871.

(94) Woertz, E. Wither the self-sufficiency illusion? Food security in Arab Gulf States and the impact of COVID-19. Food Secur. 2020, 12, 757. 
(95) Kapur, A.; Hod, M. Maternal health and non-communicable disease prevention: An investment case for the post COVID-19 world and need for better health economic data. Int. J. Gynecol. Obstet. 2020, 150 (2), 151-158.

(96) Gasmi, A.; Noor, S.; Tippairote, T.; Dadar, M.; Menzel, A.; Bjorklund, G. Individual risk management strategy and potential therapeutic options for the COVID-19 pandemic. Clin. Immunol. 2020, 215, 108409.

(97) Brauer, M.; Zhao, J. T.; Bennitt, F. B.; Stanaway, J. D. Global Access to Handwashing: Implications for COVID-19 Control in LowIncome Countries. Environ. Health Perspect. 2020, 128 (5), 057005.

(98) Stoler, J.; Jepson, W. E.; Wutich, A. Beyond handwashing: Water insecurity undermines COVID-19 response in developing areas. J. Glob. Health 2020, 10 (1), No. 010355.

(99) Tang, J. W.; Marr, L. C.; Li, Y.; Dancer, S. J. Covid-19 has redefined airborne transmission. BMJ. 2021, 373, n913.

(100) Zhang, R.; Li, Y.; Zhang, A. L.; Wang, Y.; Molina, M. J. Identifying airborne transmission as the dominant route for the spread of COVID-19. Proc. Natl. Acad. Sci. U. S. A. 2020, 117 (26), 1485714863.

(101) Andreasen, V.; Viboud, C.; Simonsen, L. Epidemiologic characterization of the 1918 influenza pandemic summer wave in Copenhagen: implications for pandemic control strategies. J. Infect. Dis. 2008, 197 (2), 270-8.

(102) Ritchie, H.; Ortiz-Ospina, E.; Beltekian, D.; Mathieu, E.; Hasell, J.; Macdonald, B.; Giattino, C.; Roser, M.; Yunits, B.; Woerden, E. v.; Gavrilov, D.; Bergel, M.; Ahmad, S.; Crawford, J. Mortality risk of COVID-19. Our World in Data. https:// ourworldindata.org/mortality-risk-covid (accessed Dec 2, 2020).

(103) Rajgor, D. D.; Lee, M. H.; Archuleta, S.; Bagdasarian, N.; Quek, S. C. The many estimates of the COVID-19 case fatality rate. Lancet Infect. Dis. 2020, 20 (7), 776-777.

(104) Calder, R. S. D.; Bromage, S.; Sunderland, E. M. Risk tradeoffs associated with traditional food advisories for Labrador Inuit. Environ. Res. 2019, 168, 496-506.

(105) Reichert, P.; Borsuk, M. E. Does high forecast uncertainty preclude effective decision support? Environ. Modell. Softw. 2005, 20, 991-1001.

(106) Scoblic, J. P.; Tetlock, P. E. A Better crystal ball: the right way to think about the future. Foreign Affairs 2020, 99 (6), 10-19.

(107) Kang, D.; Jeong, G.; Wicaksono, A. Water, energy, and food nexus: review of global implementation and simulation model development. Water Policy 2017, 19 (3), 440-462. 


\section{Supporting Information}

\section{COVID-19 reveals vulnerabilities of the food-energy-water nexus to viral pandemics}

Ryan S.D. Calder a,b,c,d, ${ }^{\text {a }}$, Caitlin Grady e,f, Marc Jeuland g,h,i, Christine J. Kirchhoff ${ }^{j}$, Rebecca L. Hale ${ }^{\mathrm{k}}$ and Rebecca L. Muenich ${ }^{1}$

${ }^{a}$ Department of Population Health Sciences, Virginia Tech, Blacksburg, VA, 24061, USA

${ }^{\mathrm{b}}$ Faculty of Health Sciences, Virginia Tech, Roanoke, VA, 24016, USA

${ }^{\mathrm{c}}$ Global Change Center, Virginia Tech, Blacksburg, VA, 24061, USA

${ }^{\mathrm{d}}$ Department of Civil and Environmental Engineering, Duke University, Durham, NC, 27708, USA

${ }^{\mathrm{e}}$ Department of Civil and Environmental Engineering, Pennsylvania State University, University Park, PA,16802, USA

${ }_{\mathrm{f}}^{\mathrm{f}}$ Rock Ethics Institute, Pennsylvania State University, University Park, PA, 16802, USA

${ }^{g}$ Sanford School of Public Policy, Duke University, Durham, NC, 27708, USA

${ }^{\text {h }}$ Global Health Institute, Duke University, Durham, NC, 27708, USA

${ }^{\mathrm{i}} \mathrm{RWI}-$ Leibniz Institute for Economic Research, 45128 Essen, Germany

${ }^{\mathrm{j}}$ Department of Civil and Environmental Engineering, University of Connecticut, Storrs, CT, 06269, USA

${ }^{\mathrm{k}}$ Department of Biological Sciences, Idaho State University, Pocatello, ID, 83209, USA

${ }^{1}$ School of Sustainable Engineering and the Built Environment, Arizona State University, Tempe, AZ, 85281, USA

* Contact: Department of Population Health Sciences (0442), Rm. 389, 205 Duck Pond Dr., Blacksburg, VA,

24061; phone: (540) 231-2430; fax: (540) 231-7007; email: rsdc@,vt.edu

\section{Supporting tables}

Table S1: Web of Science (WoS) search syntax ...................................................................... 2

Table S2: Number of articles excluded from results of WoS search for each exclusion reason .... 3

Table S3: Articles returned from WoS and excluded sorted by exclusion reason........................... 4

Table S4: Articles returned from WoS and reviewed for causal relations …………..................... 13

Table S5: Summary of NexisUni search syntaxes..................................................................... 21

Table S6: Summary of causal relations with articles invoking each ........................................... 23

Table S7: Terms by semantic similarity to "government" for groups of popular press articles... 28

Table S8: Terms by semantic similarity to "market" for groups of popular press articles........... 29

\section{Supporting figures}

Figure S1: Distribution of news/media articles by article type and industry................................ 20

Figure S2: Word frequency in news/media articles returned from NexisUni .............................. 27 
Table S1: Web of Science search syntax for articles addressing the interaction between COVID19 and the food-energy-water nexus. Syntax expressed with symbolic representations of strings for search terms associated with COVID-19 $\left(S_{\text {Covid }}\right)$, food $\left(S_{F o o d}\right)$, energy $\left(S_{\text {Energy }}\right)$ and water $\left(S_{\text {Water }}\right)$ which are each is defined below. $\mathrm{AB}=$ abstract; $\mathrm{PY}=$ publication year. ${ }^{*}$ is a wildcard.

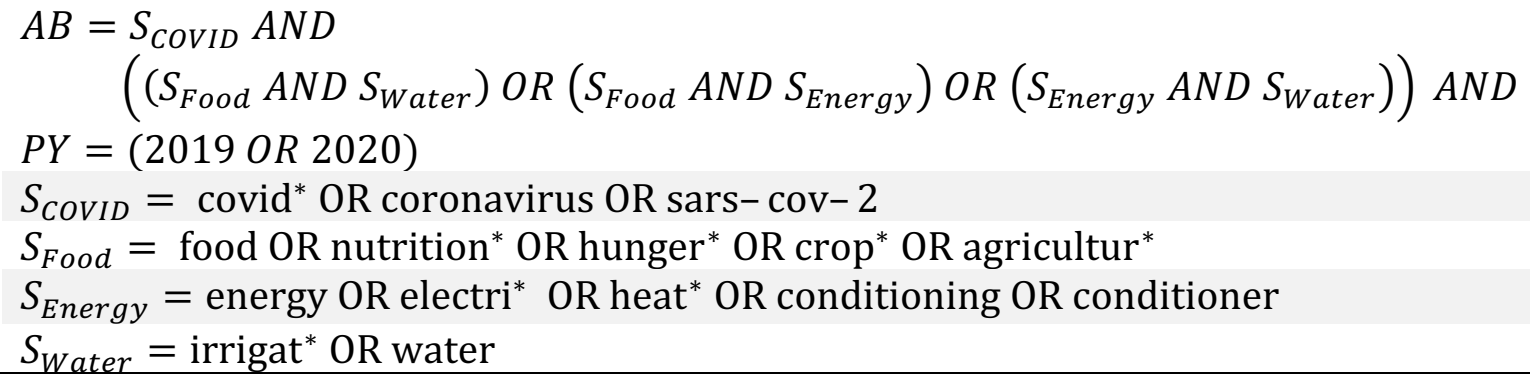


Table S2: Total number of articles excluded from results of WoS search for each exclusion reason (refer to SI Table S3 for a list of all papers excluded by reason)

\begin{tabular}{lc}
\hline Exclusion condition & Number excluded \\
\hline Biomedical research & 49 \\
Technology design & 15 \\
No connection (or tangential connection) to COVID-19 & 14 \\
Case reports and clinical care research and advice & 8 \\
Healthcare occupational safety & 7 \\
Transmission scenarios research & 5 \\
\hline Total & 98 \\
\hline
\end{tabular}


Table S3: Articles returned from Web of Science (WoS) and excluded sorted by exclusion reason

\begin{tabular}{|c|c|c|c|c|}
\hline No. & Title & $\begin{array}{c}\text { First } \\
\text { author }\end{array}$ & Journal & DOI \\
\hline \multicolumn{5}{|c|}{ Biomedical research } \\
\hline 1 & $\begin{array}{l}\text { A comparative study of the laboratory } \\
\text { features of COVID-19 and other viral } \\
\text { pneumonias in the recovery stage }\end{array}$ & Zhao, GL & $\begin{array}{l}\text { J Clin Lab } \\
\text { Anal }\end{array}$ & $\begin{array}{l}10.1002 / \mathrm{jcla} \\
.23483\end{array}$ \\
\hline 2 & $\begin{array}{l}\text { A recombinant Lactobacillus plantarum } \\
\text { strain expressing the spike protein of SARS- } \\
\text { CoV-2 }\end{array}$ & Wang, MP & $\begin{array}{l}\text { Int J Biol } \\
\text { Macromol }\end{array}$ & $\begin{array}{l}\text { 10.1016/j.ij } \\
\text { biomac. } 202 \\
0.05 .239\end{array}$ \\
\hline 3 & $\begin{array}{l}\text { A review of properties, nutritional and } \\
\text { pharmaceutical applications of Moringa } \\
\text { oleifera: integrative approach on } \\
\text { conventional and traditional Asian medicine }\end{array}$ & Meireles, D & $\begin{array}{l}\text { Adv Tradit } \\
\text { Med }\end{array}$ & $\begin{array}{l}10.1007 / \mathrm{s} 13 \\
596-020- \\
00468-0\end{array}$ \\
\hline 4 & $\begin{array}{l}\text { Amantadine disrupts lysosomal gene } \\
\text { expression: A hypothesis for COVID19 } \\
\text { treatment }\end{array}$ & $\begin{array}{l}\text { Smieszek, } \\
\text { SP }\end{array}$ & $\begin{array}{l}\text { Int J } \\
\text { Antimicrob } \\
\text { Agents }\end{array}$ & $\begin{array}{l}\text { 10.1016/j.ija } \\
\text { ntimicag.20 } \\
20.106004\end{array}$ \\
\hline 5 & $\begin{array}{l}\text { Body composition findings by computed } \\
\text { tomography in SARS-CoV-2 patients: } \\
\text { increased risk of muscle wasting in obesity }\end{array}$ & Gualtieri, $\mathrm{P}$ & $\begin{array}{l}\text { Int J Mol } \\
\text { Sci }\end{array}$ & $\begin{array}{l}10.3390 / \mathrm{ijm} \\
\text { s21134670 }\end{array}$ \\
\hline 6 & $\begin{array}{l}\text { C-phycocyanin of spirulina plantesis } \\
\text { inhibits NSP12 required for replication of } \\
\text { SARS-CoV-2: a novel finding in-silico }\end{array}$ & Raj, TK & $\begin{array}{l}\text { Int J Pharm } \\
\text { Sci Res }\end{array}$ & $\begin{array}{l}\text { 10.13040/IJ } \\
\text { PSR.0975- } \\
8232.11(9) \\
4271-78\end{array}$ \\
\hline 7 & $\begin{array}{l}\text { Conformational transition of SARS-CoV-2 } \\
\text { spike glycoprotein between its closed and } \\
\text { open states }\end{array}$ & Gur, M & $\begin{array}{l}\text { J Chem } \\
\text { Phys }\end{array}$ & $\begin{array}{l}10.1063 / 5.0 \\
011141\end{array}$ \\
\hline 8 & $\begin{array}{l}\text { COVID-19 and cardiovascular risk: } \\
\text { susceptibility to infection to SARS-CoV-2, } \\
\text { severity and prognosis of COVID-19 and } \\
\text { blockade of the renin-angiotensin- } \\
\text { aldosterone system. An evidence-based } \\
\text { viewpoint }\end{array}$ & $\begin{array}{l}\text { Cappuccio, } \\
\text { FP }\end{array}$ & $\begin{array}{l}\text { Nutr Metab } \\
\text { Cardiovasc } \\
\text { Dis }\end{array}$ & $\begin{array}{l}\text { 10.1016/j.nu } \\
\text { mecd.2020. } \\
05.013\end{array}$ \\
\hline 9 & $\begin{array}{l}\text { COVID-19 and comorbidities: a role for } \\
\text { dipeptidyl peptidase } 4 \text { (DPP4) in disease } \\
\text { severity? }\end{array}$ & $\begin{array}{l}\text { Bassen- } \\
\text { dine, MF }\end{array}$ & J Diabetes & $\begin{array}{l}10.1111 / 175 \\
3- \\
0407.13052\end{array}$ \\
\hline 10 & $\begin{array}{l}\text { Debunking cannabidiol as a treatment for } \\
\text { COVID-19: time for the FDA to adopt a } \\
\text { focused deterrence model? }\end{array}$ & Shover, CL & Cureus & $\begin{array}{l}10.7759 / \text { cur } \\
\text { eus. } 8671\end{array}$ \\
\hline 11 & $\begin{array}{l}\text { Drug repurposing against SARS-CoV-2 } \\
\text { using E-pharmacophore based virtual } \\
\text { screening, molecular docking and molecular } \\
\text { dynamics with main protease as the target }\end{array}$ & Arun, $\mathrm{KG}$ & $\begin{array}{l}\text { J Biomol } \\
\text { Struct Dyn }\end{array}$ & $\begin{array}{l}10.1080 / 073 \\
91102.2020 . \\
1779819\end{array}$ \\
\hline
\end{tabular}


Table S3: Articles returned from WoS and excluded sorted by exclusion reason (cont'd)

\begin{tabular}{|c|c|c|c|c|}
\hline No. & Title & $\begin{array}{c}\text { First } \\
\text { author }\end{array}$ & Journal & DOI \\
\hline \multicolumn{5}{|c|}{ Biomedical research (cont'd) } \\
\hline 12 & $\begin{array}{l}\text { Epidemiological Determinants of Acute } \\
\text { Respiratory Syndrome Coronavirus-2 } \\
\text { Disease Pandemic and The Role of the } \\
\text { Bacille-Calmette-Guerin Vaccine in } \\
\text { Reducing Morbidity and Mortality }\end{array}$ & $\begin{array}{l}\text { Singh, } \\
\text { BR }\end{array}$ & $\begin{array}{l}\text { J Pure Appl } \\
\text { Microbiol }\end{array}$ & $\begin{array}{l}\text { 10.22207/JPA } \\
\text { M.14.SPL1.39 }\end{array}$ \\
\hline 13 & $\begin{array}{l}\text { Hesperidin and SARS-CoV-2: New Light } \\
\text { on the Healthy Function of Citrus Fruits }\end{array}$ & $\begin{array}{l}\text { Bellavite, } \\
\text { P }\end{array}$ & $\begin{array}{l}\text { Antiox- } \\
\text { idants }\end{array}$ & $\begin{array}{l}\text { 10.3390/antiox } \\
9080742\end{array}$ \\
\hline 14 & $\begin{array}{l}\text { High affinity interaction of Solanum } \\
\text { tuberosum and Brassica juncea residue } \\
\text { smoke water compounds with proteins } \\
\text { involved in coronavirus infection }\end{array}$ & Dave, GS & $\begin{array}{l}\text { Phytother } \\
\text { Res }\end{array}$ & $\begin{array}{l}10.1002 / \text { ptr.67 } \\
96\end{array}$ \\
\hline 15 & $\begin{array}{l}\text { Hydroxychloroquine alternatives for } \\
\text { chronic disease: response to a growing } \\
\text { shortage amid the global COVID-19 } \\
\text { pandemic }\end{array}$ & $\begin{array}{l}\text { Husayn, } \\
\text { SS }\end{array}$ & $\begin{array}{l}\text { J Pharm } \\
\text { Pract }\end{array}$ & $\begin{array}{l}10.1177 / 08971 \\
90020942658\end{array}$ \\
\hline 16 & $\begin{array}{l}\text { Hypermetabolism and coronavirus disease } \\
2019\end{array}$ & $\mathrm{Yu}, \mathrm{PJ}$ & $\begin{array}{l}\text { J Parenter } \\
\text { Enter Nutr }\end{array}$ & $\begin{array}{l}\text { 10.1002/jpen.1 } \\
948\end{array}$ \\
\hline 17 & $\begin{array}{l}\text { Immunomodulatory effects of zinc as a } \\
\text { supportive strategies for COVID-19 }\end{array}$ & $\begin{array}{l}\text { Tayyib, } \\
\text { NA }\end{array}$ & $\begin{array}{l}\text { J Pharm } \\
\text { Res Int }\end{array}$ & $\begin{array}{l}10.9734 / \mathrm{JPRI} / \\
2020 / \mathrm{v} 32 \mathrm{i} 1330 \\
577\end{array}$ \\
\hline 18 & $\begin{array}{l}\text { Impact of botanical fermented foods on } \\
\text { metabolic biomarkers and gut microbiota } \\
\text { in adults with metabolic syndrome and } \\
\text { type } 2 \text { diabetes: a systematic review } \\
\text { protocol }\end{array}$ & Chan, M & BMJ Open & $\begin{array}{l}\text { 10.1136/bmjop } \\
\text { en-2019- } \\
029242\end{array}$ \\
\hline 19 & $\begin{array}{l}\text { In silico identification of widely used and } \\
\text { well-tolerated drugs as potential SARS- } \\
\text { CoV-2 3C-like protease and viral RNA- } \\
\text { dependent RNA polymerase inhibitors for } \\
\text { direct use in clinical trials }\end{array}$ & Gul, S & $\begin{array}{l}\text { J Biomol } \\
\text { Struct Dyn }\end{array}$ & $\begin{array}{l}10.1080 / 07391 \\
102.2020 .1802 \\
346\end{array}$ \\
\hline 20 & $\begin{array}{l}\text { In silico investigation of spice molecules as } \\
\text { potent inhibitor of SARS-CoV-2 }\end{array}$ & Rout, J & $\begin{array}{l}\text { J Biomol } \\
\text { Struct Dyn }\end{array}$ & $\begin{array}{l}10.1080 / 07391 \\
102.2020 .1819 \\
879\end{array}$ \\
\hline 21 & $\begin{array}{l}\text { In silico screening of potential spike } \\
\text { glycoprotein inhibitors of SARS-CoV-2 } \\
\text { with drug repurposing strategy }\end{array}$ & Wei, TZ & $\begin{array}{l}\text { Chin J } \\
\text { Integr Med }\end{array}$ & $\begin{array}{l}10.1007 / \mathrm{s} 1165 \\
5-020-3427-6\end{array}$ \\
\hline 22 & $\begin{array}{l}\text { Influence of different inactivation methods } \\
\text { on severe acute respiratory syndrome } \\
\text { coronavirus } 2 \text { RNA copy number }\end{array}$ & Chen, HL & $\begin{array}{l}\text { J Clin } \\
\text { Microbiol }\end{array}$ & $\begin{array}{l}\text { 10.1128/JCM. } \\
00958-20\end{array}$ \\
\hline
\end{tabular}


Table S3: Articles returned from WoS and excluded sorted by exclusion reason (cont'd)

\begin{tabular}{|c|c|c|c|c|}
\hline No. & Title & $\begin{array}{c}\text { First } \\
\text { author }\end{array}$ & Journal & DOI \\
\hline \multicolumn{5}{|c|}{ Biomedical research (cont'd) } \\
\hline 23 & $\begin{array}{l}\text { Lead molecule prediction and characterization } \\
\text { for designing MERS-CoV 3C-like protease } \\
\text { inhibitors: an in silico approach }\end{array}$ & $\begin{array}{l}\text { Rahman, } \\
\text { MM }\end{array}$ & $\begin{array}{l}\text { Curr } \\
\text { Comput - } \\
\text { Aided } \\
\text { Drug Des }\end{array}$ & $\begin{array}{l}10.2174 / 157 \\
3409914666 \\
1806291519 \\
06\end{array}$ \\
\hline 24 & $\begin{array}{l}\text { Lung microbiota in the acute respiratory } \\
\text { disease: from coronavirus to metabolomics }\end{array}$ & $\begin{array}{l}\text { Fanos, } \\
\text { V }\end{array}$ & $\begin{array}{l}\text { J Pediatric } \\
\text { Neonatal } \\
\text { Individ } \\
\text { Med }\end{array}$ & $\begin{array}{l}10.7363 / 090 \\
139\end{array}$ \\
\hline 25 & $\begin{array}{l}\text { Microbiota modulating nutritional approaches } \\
\text { to countering the effects of viral respiratory } \\
\text { infections including SARS-CoV-2 through } \\
\text { promoting metabolic and immune fitness with } \\
\text { probiotics and plant bioactives }\end{array}$ & $\begin{array}{l}\text { Shinde, } \\
\mathrm{T}\end{array}$ & $\begin{array}{l}\text { Microorga } \\
\text { nisms }\end{array}$ & $\begin{array}{l}10.3390 / \mathrm{mic} \\
\text { roorganisms } \\
8060921\end{array}$ \\
\hline 26 & $\begin{array}{l}\text { Molecular docking, validation, dynamics } \\
\text { simulations, and pharmacokinetic prediction of } \\
\text { natural compounds against the SARS-CoV-2 } \\
\text { main-protease }\end{array}$ & $\begin{array}{l}\text { Shiva- } \\
\text { nika, C }\end{array}$ & $\begin{array}{l}\text { J Biomol } \\
\text { Struct } \\
\text { Dyn }\end{array}$ & $\begin{array}{l}10.1080 / 073 \\
91102.2020 . \\
1815584\end{array}$ \\
\hline 27 & $\begin{array}{l}\text { Natural derivatives with dual binding potential } \\
\text { against SARS-CoV-2 main protease and human } \\
\text { ACE } 2 \text { possess low oral bioavailability: a brief } \\
\text { computational analysis }\end{array}$ & $\begin{array}{l}\text { Sharma, } \\
\text { P }\end{array}$ & $\begin{array}{l}\text { J Biomol } \\
\text { Struct } \\
\text { Dyn }\end{array}$ & $\begin{array}{l}10.1080 / 073 \\
91102.2020 . \\
1794970\end{array}$ \\
\hline 28 & $\begin{array}{l}\text { Potential anti-viral activity of approved } \\
\text { repurposed drug against main protease of } \\
\text { SARS-CoV-2: an in silico based approach }\end{array}$ & $\begin{array}{l}\text { Mahan- } \\
\text { ta, S }\end{array}$ & $\begin{array}{l}\text { J Biomol } \\
\text { Struct } \\
\text { Dyn }\end{array}$ & $\begin{array}{l}10.1080 / 073 \\
91102.2020 . \\
1768902\end{array}$ \\
\hline 29 & $\begin{array}{l}\text { preliminary data related to the effect of } \\
\text { climacostol produced by the freshwater ciliate } \\
\text { Climacostomum virens on human adenovirus }\end{array}$ & $\begin{array}{l}\text { Verani, } \\
\text { M }\end{array}$ & $\begin{array}{l}\text { Viruses- } \\
\text { Basel }\end{array}$ & $\begin{array}{l}10.3390 / \mathrm{v} 12 \\
060658\end{array}$ \\
\hline 30 & $\begin{array}{l}\text { Protein reliability analysis and virtual screening } \\
\text { of natural inhibitors for SARS-CoV-2 main } \\
\text { protease (M-pro) through docking, molecular } \\
\text { mechanic \& dynamic, and ADMET profiling }\end{array}$ & $\begin{array}{l}\text { Kapusta, } \\
\mathrm{K}\end{array}$ & $\begin{array}{l}\text { J Biomol } \\
\text { Struct } \\
\text { Dyn }\end{array}$ & $\begin{array}{l}10.1080 / 073 \\
91102.2020 . \\
1806930\end{array}$ \\
\hline 31 & $\begin{array}{l}\text { Relation of dietary factors with infection and } \\
\text { mortality rates of COVID-19 across the world }\end{array}$ & $\begin{array}{l}\text { Abdu- } \\
\text { lah, DM }\end{array}$ & $\begin{array}{l}\text { J Nutr } \\
\text { Health } \\
\text { Aging }\end{array}$ & $\begin{array}{l}10.1007 / \mathrm{s} 12 \\
603-020- \\
1434-0\end{array}$ \\
\hline 32 & $\begin{array}{l}\text { Repurposing approved drugs as inhibitors of } \\
\text { SARS-CoV-2 S-protein from molecular } \\
\text { modeling and virtual screening }\end{array}$ & $\begin{array}{l}\text { de } \\
\text { Oliveira, } \\
\text { OV }\end{array}$ & $\begin{array}{l}\text { J Biomol } \\
\text { Struct } \\
\text { Dyn }\end{array}$ & $\begin{array}{l}10.1080 / 073 \\
91102.2020 \\
1772885\end{array}$ \\
\hline 33 & $\begin{array}{l}\text { Role of immune dysregulation in increased } \\
\text { mortality among a specific subset of COVID-19 } \\
\text { patients and immune-enhancement strategies } \\
\text { for combatting through nutritional supplements }\end{array}$ & Rao, KS & $\begin{array}{l}\text { Front } \\
\text { Immunol }\end{array}$ & $\begin{array}{l}10.3389 / \text { fim } \\
\text { mu.2020.01 } \\
548\end{array}$ \\
\hline
\end{tabular}


Table S3: Articles returned from WoS and excluded sorted by exclusion reason (cont'd)

\begin{tabular}{|c|c|c|c|c|}
\hline No. & Title & First author & Journal & DOI \\
\hline \multicolumn{5}{|c|}{ Biomedical research (cont'd) } \\
\hline 34 & $\begin{array}{l}\text { SARS-CoV-2 infection and some } \\
\text { controversies concerning therapy with } \\
\text { chloroquine and hydroksychloroquine: } \\
\text { case report and selected literature review }\end{array}$ & Cieplucha, $\mathrm{H}$ & $\begin{array}{l}\text { Postepy Hig } \\
\text { Med Dosw }\end{array}$ & $\begin{array}{l}10.5604 / 01 \\
3001.0014 .3 \\
589\end{array}$ \\
\hline 35 & $\begin{array}{l}\text { Selenium biofortification in the } 21^{\text {st }} \\
\text { century: status and challenges for healthy } \\
\text { human nutrition }\end{array}$ & Schiavon, $\mathrm{M}$ & Plant Soil & $\begin{array}{l}10.1007 / \mathrm{s} 11 \\
104-020- \\
04635-9\end{array}$ \\
\hline 36 & $\begin{array}{l}\text { Several coumarin derivatives and their } \\
\text { Pd(ii) complexes as potential inhibitors } \\
\text { of the main protease of SARS-CoV-2, an } \\
\text { in silico approach }\end{array}$ & $\begin{array}{l}\text { Milenkovic, } \\
\text { DA }\end{array}$ & RSC Adv & $\begin{array}{l}10.1039 / \mathrm{d} 0 \mathrm{r} \\
\mathrm{a} 07062 \mathrm{a}\end{array}$ \\
\hline 37 & $\begin{array}{l}\text { Six decades of lateral flow immunoassay: } \\
\text { from determining metabolic markers to } \\
\text { diagnosing COVID-19 }\end{array}$ & $\begin{array}{l}\text { Andryukov, } \\
\text { BG }\end{array}$ & $\begin{array}{l}\text { AIMS } \\
\text { Microbiol }\end{array}$ & $\begin{array}{l}10.3934 / \mathrm{mic} \\
\text { robiol.2020 } \\
018\end{array}$ \\
\hline 38 & $\begin{array}{l}\text { State-of-the-art tools to identify } \\
\text { druggable protein ligand of } \\
\text { SARS-CoV-2 }\end{array}$ & Azeez, SA & $\begin{array}{l}\text { Arch Med } \\
\text { Sci }\end{array}$ & $\begin{array}{l}10.5114 / \text { ao } \\
\mathrm{ms} .2020 .94 \\
046\end{array}$ \\
\hline 39 & $\begin{array}{l}\text { Structural basis of the potential binding } \\
\text { mechanism of remdesivir to SARS-CoV- } \\
2 \text { RNA-dependent RNA polymerase }\end{array}$ & Zhang, LL & $\begin{array}{l}\text { J Phys } \\
\text { Chem B }\end{array}$ & $\begin{array}{l}10.1021 / \text { acs. } \\
\text { jpcb.0c0419 } \\
8\end{array}$ \\
\hline 40 & $\begin{array}{l}\text { Structure-based drug repurposing for } \\
\text { targeting Nsp9 replicase and spike } \\
\text { proteins of severe acute respiratory } \\
\text { syndrome coronavirus } 2\end{array}$ & Chandel, V & $\begin{array}{l}\text { J Biomol } \\
\text { Struct Dyn }\end{array}$ & $\begin{array}{l}10.1080 / 073 \\
91102.2020 \\
1811773\end{array}$ \\
\hline 41 & $\begin{array}{l}\text { Structure-based virtual screening of } \\
\text { phytochemicals and repurposing of FDA } \\
\text { approved antiviral drugs unravels lead } \\
\text { molecules as potential inhibitors of } \\
\text { coronavirus 3C-like protease enzyme }\end{array}$ & Gurung, $\mathrm{AB}$ & $\begin{array}{l}\text { J King Saud } \\
\text { Univ Sci }\end{array}$ & $\begin{array}{l}10.1016 / j . j \mathrm{k} \\
\text { sus.2020.07. } \\
007\end{array}$ \\
\hline 42 & $\begin{array}{l}\text { The impact of nutrition on COVID-19 } \\
\text { susceptibility and long-term } \\
\text { consequences }\end{array}$ & Butler, MJ & $\begin{array}{l}\text { Brain Behav } \\
\text { Immun }\end{array}$ & $\begin{array}{l}10.1016 / j . b b \\
\text { i. } 2020.04 .04 \\
0\end{array}$ \\
\hline 43 & $\begin{array}{l}\text { The inhibitory effect of some natural } \\
\text { bioactive compounds against SARS- } \\
\text { CoV-2 main protease: insights from } \\
\text { molecular docking analysis and } \\
\text { molecular dynamic simulation }\end{array}$ & $\begin{array}{l}\text { Abdelrheem, } \\
\text { DA }\end{array}$ & $\begin{array}{l}\text { J Environ } \\
\text { Sci Health } \\
\text { A }\end{array}$ & $\begin{array}{l}10.1080 / 109 \\
34529.2020 \\
1826192\end{array}$ \\
\hline 44 & $\begin{array}{l}\text { The role of environmental factors to } \\
\text { transmission of SARS-CoV-2 (COVID- } \\
\text { 19) }\end{array}$ & Eslami, $\mathrm{H}$ & $\begin{array}{l}\text { AMB } \\
\text { Express }\end{array}$ & $\begin{array}{l}10.1186 / \mathrm{s} 13 \\
568-020- \\
01028-0\end{array}$ \\
\hline
\end{tabular}


Table S3: Articles returned from WoS and excluded sorted by exclusion reason (cont'd)

\begin{tabular}{|c|c|c|c|c|}
\hline No. & Title & First author & Journal & DOI \\
\hline \multicolumn{5}{|c|}{ Biomedical research (cont'd) } \\
\hline 45 & $\begin{array}{l}\text { Virtual screening, molecular dynamics } \\
\text { and structure-activity relationship studies } \\
\text { to identify potent approved drugs for } \\
\text { Covid-19 treatment }\end{array}$ & $\begin{array}{l}\text { Rahman, } \\
\text { MM }\end{array}$ & $\begin{array}{l}\text { J Biomol } \\
\text { Struct } \\
\text { Dyn }\end{array}$ & $\begin{array}{l}10.1080 / 0739 \\
1102.2020 .17 \\
94974\end{array}$ \\
\hline 46 & $\begin{array}{l}\text { Vitamin B12 may inhibit RNA- } \\
\text { dependent-RNA polymerase activity of } \\
\text { nsp12 from theSARS-CoV-2 virus }\end{array}$ & $\begin{array}{l}\text { Narayanan, } \\
\mathrm{N}\end{array}$ & $\begin{array}{l}\text { IUBMB } \\
\text { Life }\end{array}$ & $\begin{array}{l}10.1002 / \text { iub. } 2 \\
359\end{array}$ \\
\hline 47 & $\begin{array}{l}\text { Why are lopinavir and ritonavir effective } \\
\text { against the newly emerged coronavirus } \\
2019 \text { ? Atomistic insights into the } \\
\text { inhibitory mechanisms }\end{array}$ & Nutho, B & $\begin{array}{l}\text { Biochem- } \\
\text { istry }\end{array}$ & $\begin{array}{l}10.1021 / \mathrm{acs} . \mathrm{b} \\
\text { iochem.0c001 } \\
60\end{array}$ \\
\hline 48 & $\begin{array}{l}\text { Prevention of community-acquired } \\
\text { pneumonia in children: South African } \\
\text { Thoracic Society guidelines (part 4) }\end{array}$ & Zar, HJ & $\begin{array}{l}\text { S Afr Med } \\
\text { J }\end{array}$ & $\begin{array}{l}\text { 10.7196/SAM } \\
\text { J.2020.v110i8 } \\
.15024\end{array}$ \\
\hline 49 & $\begin{array}{l}\text { Nicotinamide riboside-the current state of } \\
\text { research and therapeutic uses }\end{array}$ & Mehmel, M & Nutrients & $\begin{array}{l}10.3390 / \text { nu } 12 \\
061616\end{array}$ \\
\hline \multicolumn{5}{|c|}{ Case reports and clinical care } \\
\hline 50 & $\begin{array}{l}\text { Acute acalculous cholecystitis on a } \\
\text { COVID-19 patient: a case report }\end{array}$ & Mattone, E & $\begin{array}{l}\text { Ann Med } \\
\text { Surg }\end{array}$ & $\begin{array}{l}\text { 10.1016/j.ams } \\
\text { u.2020.08.027 }\end{array}$ \\
\hline 51 & $\begin{array}{l}\text { Is naso-pharyngeal swab always safe for } \\
\text { SARS-CoV-2 testing? An unusual, } \\
\text { accidental foreign body swallowing }\end{array}$ & De Luca, L & $\begin{array}{l}\text { J Clin } \\
\text { Gastroente } \\
\text { rol }\end{array}$ & $\begin{array}{l}10.1007 / \mathrm{s} 123 \\
28-020- \\
01236-\mathrm{y}\end{array}$ \\
\hline 52 & $\begin{array}{l}\text { Early nutritional supplementation in non- } \\
\text { critically ill patients hospitalized for the } \\
2019 \text { novel coronavirus disease (COVID- } \\
\text { 19): rationale and feasibility of a shared } \\
\text { pragmatic protocol }\end{array}$ & $\begin{array}{l}\text { Caccialanza, } \\
\mathrm{R}\end{array}$ & Nutrition & $\begin{array}{l}\text { 10.1016/j.nut. } \\
\text { 2020.110835 }\end{array}$ \\
\hline 53 & $\begin{array}{l}\text { Easy-to-prescribe nutrition support in the } \\
\text { intensive care in the era of COVID- } 19\end{array}$ & $\begin{array}{l}\text { de } \\
\text { Watteville, A }\end{array}$ & $\begin{array}{l}\text { Clin Nutr } \\
\text { ESPEN }\end{array}$ & $\begin{array}{l}\text { 10.1016/j.clne } \\
\text { sp.2020.07.01 } \\
5\end{array}$ \\
\hline 54 & $\begin{array}{l}\text { Normothermia is best achieved by } \\
\text { warming above and below with pre- } \\
\text { warming adjunct: a comparison of } \\
\text { conductive fabric versus forced-air and } \\
\text { water }\end{array}$ & Ohki, K & $\begin{array}{l}\text { Surg } \\
\text { Technol } \\
\text { Int }\end{array}$ & \\
\hline 55 & $\begin{array}{l}\text { Nutritional Support in Coronavirus } 2019 \\
\text { Disease }\end{array}$ & $\begin{array}{l}\text { Stachowska, } \\
\text { E }\end{array}$ & $\begin{array}{l}\text { Medi- } \\
\text { cinia- } \\
\text { Lithuania }\end{array}$ & $\begin{array}{l}10.3390 / \text { medi } \\
\text { cina56060289 }\end{array}$ \\
\hline 56 & $\begin{array}{l}\text { Position paper of the Italian association } \\
\text { of medical specialists in dietetics and } \\
\text { clinical nutrition (ANSISA) on } \\
\text { nutritional management of patients with } \\
\text { COVID-19 disease }\end{array}$ & Cena, $\mathrm{H}$ & $\begin{array}{l}\text { Mediterr J } \\
\text { Nutr } \\
\text { Metab }\end{array}$ & $\begin{array}{l}10.3233 / \mathrm{MN} \\
\mathrm{M}-200425\end{array}$ \\
\hline
\end{tabular}


Table S3: Articles returned from WoS and excluded sorted by exclusion reason (cont'd)

\begin{tabular}{|c|c|c|c|c|}
\hline No. & Title & $\begin{array}{l}\text { First } \\
\text { author }\end{array}$ & Journal & DOI \\
\hline \multicolumn{5}{|c|}{ Case reports and clinical care (cont'd) } \\
\hline 57 & $\begin{array}{l}\text { Postintubation Dysphagia During } \\
\text { COVID-19 Outbreak-Contemporary } \\
\text { Review }\end{array}$ & Frajkova, Z & Dysphagia & $\begin{array}{l}10.1007 / \mathrm{s} 004 \\
55-020- \\
10139-6\end{array}$ \\
\hline \multicolumn{5}{|c|}{ Economics - No connection (or tangential connection) to COVID-19 } \\
\hline 58 & $\begin{array}{l}\text { Regional specialization and } \\
\text { agglomeration effects in the Russian } \\
\text { economy }\end{array}$ & $\begin{array}{l}\text { Rastv- } \\
\text { ortseva, SN }\end{array}$ & $\begin{array}{l}\text { Econ Soc } \\
\text { Changes- } \\
\text { Facts } \\
\text { Trends } \\
\text { Forecast }\end{array}$ & $\begin{array}{l}\text { 10.15838/esc. } \\
\text { 2020.3.69.4 }\end{array}$ \\
\hline 59 & $\begin{array}{l}\text { The Discounted money value of human } \\
\text { lives lost due to COVID-19 in Spain }\end{array}$ & Kirigia, JM & J Health Res & $\begin{array}{l}\text { 10.1108/JHR- } \\
04-2020-0116\end{array}$ \\
\hline 60 & $\begin{array}{l}\text { The effectiveness of self-sufficiency } \\
\text { policy: international price transmissions } \\
\text { in beef markets }\end{array}$ & Guo, $\mathrm{J}$ & $\begin{array}{l}\text { Sustaina- } \\
\text { bility }\end{array}$ & $\begin{array}{l}10.3390 / \text { su } 12 \\
156073\end{array}$ \\
\hline 61 & $\begin{array}{l}\text { Transformation of the strategy of state } \\
\text { economic policy in modern conditions }\end{array}$ & $\begin{array}{l}\text { Petrun-- } \\
\text { enko, I }\end{array}$ & $\begin{array}{l}\text { Balt J Econ } \\
\text { Stud }\end{array}$ & $\begin{array}{l}10.30525 / 225 \\
6-0742 / 2020- \\
6-3-107-113\end{array}$ \\
\hline \multicolumn{5}{|c|}{ Education - No connection (or tangential connection) to COVID-19 } \\
\hline 62 & $\begin{array}{l}\text { Development and use of kitchen } \\
\text { chemistry home practical activities } \\
\text { during unanticipated campus closures }\end{array}$ & Schultz, M & $\begin{array}{l}\text { J Chem } \\
\text { Educ }\end{array}$ & $\begin{array}{l}10.1021 / \text { acs.jc } \\
\text { hemed.0c006 } \\
20\end{array}$ \\
\hline 63 & $\begin{array}{l}\text { Visualizing the invisible: class } \\
\text { excursions to ignite children's enthusiasm } \\
\text { for microbes }\end{array}$ & $\begin{array}{l}\text { Mc- } \\
\text { Genity, TJ }\end{array}$ & $\begin{array}{l}\text { Microb } \\
\text { Biotechnol }\end{array}$ & $\begin{array}{l}10.1111 / 1751 \\
-7915.13576\end{array}$ \\
\hline \multicolumn{5}{|c|}{ Governance - No connection (or tangential connection) to COVID-19 } \\
\hline 64 & $\begin{array}{l}\text { From Four-Way Linking to a One Health } \\
\text { Platform in Egypt: institutionalisation of } \\
\text { a multidisciplinary and multisectoral One } \\
\text { Health system }\end{array}$ & Allal, L & $\begin{array}{l}\text { Rev Sci } \\
\text { Tech }\end{array}$ & $\begin{array}{l}\text { 10.20506/rst.3 } \\
8.1 .2958\end{array}$ \\
\hline 65 & $\begin{array}{l}\text { Political intrusions into the international } \\
\text { health regulations treaty and its impact } \\
\text { on management of rapidly emerging } \\
\text { zoonotic pandemics: what history tells us }\end{array}$ & Burkle, FM & $\begin{array}{l}\text { Prehosp } \\
\text { Disaster } \\
\text { Med }\end{array}$ & $\begin{array}{l}10.1017 / \mathrm{S} 104 \\
9023 \mathrm{X} 200005 \\
15\end{array}$ \\
\hline \multicolumn{5}{|c|}{ Healthcare occupational safety } \\
\hline 66 & $\begin{array}{l}\text { Coronavirus contamination in dental } \\
\text { clinics. New systems and operating } \\
\text { devices }\end{array}$ & $\begin{array}{l}\text { Gandolfi, } \\
\text { MG }\end{array}$ & $\begin{array}{l}\text { Dent } \\
\text { Cadmos }\end{array}$ & $\begin{array}{l}10.19256 / \text { d.ca } \\
\text { dmos.06.2020 } \\
.06\end{array}$ \\
\hline 67 & $\begin{array}{l}\text { COVID-19 in Africa: care and protection } \\
\text { for frontline healthcare workers }\end{array}$ & $\begin{array}{l}\text { Chersich, } \\
\text { MF }\end{array}$ & Glob Health & $\begin{array}{l}10.1186 / \mathrm{s} 129 \\
92-020- \\
00574-3\end{array}$ \\
\hline
\end{tabular}


Table S3: Articles returned from WoS and excluded sorted by exclusion reason (cont'd)

\begin{tabular}{|c|c|c|c|c|}
\hline No. & Title & $\begin{array}{c}\text { First } \\
\text { author }\end{array}$ & Journal & DOI \\
\hline \multicolumn{5}{|c|}{ Healthcare occupational safety (cont'd) } \\
\hline 68 & $\begin{array}{l}\text { Health issues among healthcare workers during } \\
\text { COVID-19 pandemic: a psychosomatic } \\
\text { approach }\end{array}$ & $\begin{array}{l}\text { Widjaja, } \\
\text { FF }\end{array}$ & $\begin{array}{l}\text { Acta Med } \\
\text { Indones }\end{array}$ & \\
\hline 69 & $\begin{array}{l}\text { Nutritional recommendations for healthcare } \\
\text { and essential personnel exposed to COVID-19 } \\
\text { in Latin America }\end{array}$ & $\begin{array}{l}\text { Palacios, } \\
\text { C }\end{array}$ & $\begin{array}{l}\text { Arch } \\
\text { Latinoam } \\
\text { Nutr }\end{array}$ & $\begin{array}{l}10.37527 .20 \\
19.69 .4 .005\end{array}$ \\
\hline 70 & $\begin{array}{l}\text { Pediatric endoscopy in the era of Coronavirus } \\
\text { Disease 2019: a North American Society for } \\
\text { Pediatric Gastroenterology, Hepatology, and } \\
\text { Nutrition position paper }\end{array}$ & $\begin{array}{l}\text { Walsh, } \\
\text { CM }\end{array}$ & $\begin{array}{l}\text { J Pediatr } \\
\text { Gastro-- } \\
\text { enterol } \\
\text { Nutr }\end{array}$ & $\begin{array}{l}10.1097 / \mathrm{MP} \\
\text { G.00000000 } \\
00002750\end{array}$ \\
\hline 71 & $\begin{array}{l}\text { Safe surgery during the coronavirus disease } \\
2019 \text { crisis }\end{array}$ & $\begin{array}{l}\text { Tivey, } \\
\text { DR }\end{array}$ & $\begin{array}{l}\text { ANZ J } \\
\text { Surg }\end{array}$ & $\begin{array}{l}10.1111 / \mathrm{ans} \\
.16089\end{array}$ \\
\hline 72 & $\begin{array}{l}\text { Strategic implementation of dental infection } \\
\text { control in resource-poor jurisdictions during } \\
\text { COVID-19 pandemic: a perspective from } \\
\text { South Africa }\end{array}$ & $\begin{array}{l}\text { Blignaut, } \\
\mathrm{E}\end{array}$ & $\begin{array}{l}\text { Acta } \\
\text { Odontol } \\
\text { Scand }\end{array}$ & $\begin{array}{l}10.1080 / 000 \\
16357.2020 \\
1804073\end{array}$ \\
\hline \multicolumn{5}{|c|}{ Information technology - No connection (or tangential connection) to COVID-19 } \\
\hline 73 & $\begin{array}{l}\text { An Infoveillance system for detecting and } \\
\text { tracking relevant topics from Italian tweets } \\
\text { during the COVID-19 event }\end{array}$ & $\begin{array}{l}\text { De } \\
\text { Santis, E }\end{array}$ & $\begin{array}{l}\text { IEEE } \\
\text { Access }\end{array}$ & $\begin{array}{l}\text { 10.1109/AC } \\
\text { CESS.2020. } \\
3010033\end{array}$ \\
\hline 74 & We all deserve broadband & $\begin{array}{l}\text { Higgin-- } \\
\text { botham, } \\
\text { S }\end{array}$ & $\begin{array}{l}\text { IEEE } \\
\text { Spectr }\end{array}$ & $\begin{array}{l}\text { 10.1109/MS } \\
\text { PEC.2020.9 } \\
078451\end{array}$ \\
\hline \multicolumn{5}{|c|}{ Marketing - No connection (or tangential connection) to COVID-19 } \\
\hline 75 & $\begin{array}{l}\text { Impact of the perceived threat of COVID-19 } \\
\text { on variety-seeking }\end{array}$ & Kim, J & $\begin{array}{l}\text { Australas } \\
\text { Mark J }\end{array}$ & $\begin{array}{l}10.1016 / \text { j.au } \\
\text { smj.2020.07 } \\
.001\end{array}$ \\
\hline \multicolumn{5}{|c|}{ Nutrition - No connection (or tangential connection) to COVID-19 } \\
\hline 76 & $\begin{array}{l}\text { Food choices of young adults in the United } \\
\text { States of America: a scoping review }\end{array}$ & $\begin{array}{l}\text { Powell, } \\
\text { PK }\end{array}$ & Adv Nutr & $\begin{array}{l}10.1093 / \mathrm{adv} \\
\text { ances/nmy1 } \\
16\end{array}$ \\
\hline \multicolumn{5}{|c|}{ Political science - No connection (or tangential connection) to COVID-19 } \\
\hline 77 & The Middle East at a time of negative certainty & $\begin{array}{l}\text { Zvyagel- } \\
\text { skaya, ID }\end{array}$ & $\begin{array}{l}\text { Mirovaya } \\
\text { Ekon } \\
\text { Mezhdu- } \\
\text { nar Otnos }\end{array}$ & $\begin{array}{l}10.20542 / 01 \\
31-2227- \\
2020-64-6- \\
94-103\end{array}$ \\
\hline \multicolumn{5}{|c|}{ Technology design } \\
\hline 78 & $\begin{array}{l}\text { A laboratory-based study examining the } \\
\text { properties of silk fabric to evaluate its potential } \\
\text { as a protective barrier for personal protective } \\
\text { equipment and as a functional material for face } \\
\text { coverings during the COVID- } 19 \text { pandemic }\end{array}$ & $\begin{array}{l}\text { Parlin, } \\
\text { AF }\end{array}$ & PLoS One & $\begin{array}{l}\text { 10.1371/jou } \\
\text { rnal.pone.02 } \\
39531\end{array}$ \\
\hline
\end{tabular}


Table S3: Articles returned from WoS and excluded sorted by exclusion reason (cont'd)

\begin{tabular}{|c|c|c|c|c|}
\hline No. & Title & First author & Journal & DOI \\
\hline \multicolumn{5}{|c|}{ Technology design (cont'd) } \\
\hline 79 & $\begin{array}{l}\text { A novel and stable way for energy } \\
\text { harvesting from Bi2Te3Se alloy based } \\
\text { semitransparent photo-thermoelectric } \\
\text { module }\end{array}$ & Fatima, N & $\begin{array}{l}\text { J Alloys } \\
\text { Compd }\end{array}$ & $\begin{array}{l}10.1016 / j . j a l \\
\text { lcom.2020.1 } \\
56702\end{array}$ \\
\hline 80 & $\begin{array}{l}\text { Charged PVDF multilayer nanofiber } \\
\text { filter in filtering simulated airborne } \\
\text { novel coronavirus (COVID-19) using } \\
\text { ambient nano-aerosols }\end{array}$ & $\begin{array}{l}\text { Leung, } \\
\text { WWF }\end{array}$ & $\begin{array}{l}\text { Sep Purif } \\
\text { Technol }\end{array}$ & $\begin{array}{l}\text { 10.1016/j.sep } \\
\text { pur.2020.116 } \\
887\end{array}$ \\
\hline 81 & $\begin{array}{l}\text { Decontamination methods for reuse of } \\
\text { filtering facepiece respirators }\end{array}$ & $\begin{array}{l}\text { Su-Velez, } \\
\text { BM }\end{array}$ & $\begin{array}{l}\text { JAMA } \\
\text { Otolaryngol } \\
\text { Head Neck } \\
\text { Surg }\end{array}$ & $\begin{array}{l}10.1001 / \mathrm{jam} \\
\text { aoto.2020.14 } \\
23\end{array}$ \\
\hline 82 & $\begin{array}{l}\text { Electrostatic charged nanofiber filter for } \\
\text { filtering airborne novel coronavirus } \\
\text { (COVID-19) and nano-aerosols }\end{array}$ & $\begin{array}{l}\text { Leung, } \\
\text { WWF }\end{array}$ & Saf Sci & $\begin{array}{l}10.1016 / j . s s c \\
\text { i. } 2020.10483 \\
0\end{array}$ \\
\hline 83 & $\begin{array}{l}\text { Engineering graphene oxide/water } \\
\text { interface from first principles to } \\
\text { experiments for electrostatic protective } \\
\text { composites }\end{array}$ & Valentini, L & $\begin{array}{l}\text { Sep Purif } \\
\text { Technol }\end{array}$ & $\begin{array}{l}10.1016 / j . s e p \\
\text { pur.2020.116 } \\
886\end{array}$ \\
\hline 84 & $\begin{array}{l}\text { Industrial lubricant removal using an } \\
\text { ultrasonically activated water stream, } \\
\text { with potential application for } \\
\text { Coronavirus decontamination and } \\
\text { infection prevention for SARS-CoV-2 }\end{array}$ & $\begin{array}{l}\text { Malakout- } \\
\text { ikhah, M }\end{array}$ & $\begin{array}{l}\text { Polymers } \\
\text { (Basel) }\end{array}$ & $\begin{array}{l}\text { 10.3390/poly } \\
\text { m12071596 }\end{array}$ \\
\hline 85 & $\begin{array}{l}\text { Internet of things (IoT) based } \\
\text { coordination system in Agri-food supply } \\
\text { chain: development of an efficient } \\
\text { framework using DEMATEL-ISM }\end{array}$ & Yadav, S & $\begin{array}{l}\text { Trans Inst } \\
\text { Met Finish }\end{array}$ & $\begin{array}{l}10.1080 / 002 \\
02967.2020 \\
1805221\end{array}$ \\
\hline 86 & $\begin{array}{l}\text { Nanobiotechnology model arising from } \\
\text { coronavirus interacting with the AQP } \\
\text { channels along the respiratory regions } \\
\text { and estimating the infectivity rate of the } \\
\text { COVID19 outbreak based on } \\
\text { temperature and direct contact rate }\end{array}$ & $\begin{array}{l}\text { Al Garalleh, } \\
\mathrm{H}\end{array}$ & $\begin{array}{l}\text { Oper Manag } \\
\text { Res }\end{array}$ & $\begin{array}{l}10.1007 / \mathrm{s} 120 \\
63-020- \\
00164-\mathrm{x}\end{array}$ \\
\hline 87 & $\begin{array}{l}\text { Photocatalytic nanowires-based air } \\
\text { filter: towards reusable protective masks }\end{array}$ & Horvath, E & $\begin{array}{l}\text { Nanosci } \\
\text { Nanotechnol } \\
\text { Lett }\end{array}$ & $\begin{array}{l}10.1166 / \mathrm{nnl} \\
2020.3077\end{array}$ \\
\hline 88 & $\begin{array}{l}\text { Properties and reactivities of } \\
\text { niclosamide in different media, a } \\
\text { potential antiviral to treatment of } \\
\text { COVID- } 19 \text { by Using DFT calculations } \\
\text { and molecular docking }\end{array}$ & Romani, D & $\begin{array}{l}\text { Adv Funct } \\
\text { Mater }\end{array}$ & $\begin{array}{l}10.1002 / \mathrm{adf} \\
\mathrm{m} .20200461 \\
5\end{array}$ \\
\hline
\end{tabular}


Table S3: Articles returned from WoS and excluded sorted by exclusion reason (cont'd)

\begin{tabular}{|c|c|c|c|c|}
\hline No. & Title & $\begin{array}{c}\text { First } \\
\text { author }\end{array}$ & Journal & DOI \\
\hline \multicolumn{5}{|c|}{ Technology design (cont'd) } \\
\hline 89 & $\begin{array}{l}\text { Electrostatic charged nanofiber filter for } \\
\text { filtering airborne novel coronavirus } \\
\text { (COVID-19) and nano-aerosols }\end{array}$ & O'Brien, $\mathrm{S}$ & $\begin{array}{l}\text { Biointerface } \\
\text { Res Appl } \\
\text { Chem }\end{array}$ & $\begin{array}{l}10.3390 / \text { en } 1 \\
3174528\end{array}$ \\
\hline 90 & $\begin{array}{l}\text { Synergy of thermochemical treatment of } \\
\text { dried distillers grains with solubles with } \\
\text { bioethanol production for increased } \\
\text { sustainability and profitability }\end{array}$ & Londhe, V & Energies & $\begin{array}{l}\text { 10.1016/j.mse } \\
\text { c. } 2020.11133 \\
0\end{array}$ \\
\hline 91 & $\begin{array}{l}\text { Unfolding the future: self-controlled } \\
\text { catalytic nanomotor in healthcare } \\
\text { system }\end{array}$ & Roos, YH & $\begin{array}{l}\text { Mat Sci Eng } \\
\text { C-Mater }\end{array}$ & $\begin{array}{l}10.1007 / \mathrm{s} 123 \\
93-020- \\
09234-\mathrm{Z}\end{array}$ \\
\hline 92 & $\begin{array}{l}\text { Water and pathogenic viruses } \\
\text { inactivation - food engineering } \\
\text { perspectives }\end{array}$ & Bhattarai, K & $\begin{array}{l}\text { Food Eng } \\
\text { Rev }\end{array}$ & $\begin{array}{l}\text { 10.3390/agric } \\
\text { ulture100602 } \\
24\end{array}$ \\
\hline \multicolumn{5}{|c|}{ Topography - No connection (or tangential connection) to COVID-19 } \\
\hline 93 & $\begin{array}{l}\text { Influence of topography on sustainable } \\
\text { land management: an analysis of } \\
\text { socioeconomic and ecodemographic } \\
\text { conditions of Nepal }\end{array}$ & $\begin{array}{l}\text { Chaudhuri, } \\
\text { S }\end{array}$ & $\begin{array}{l}\text { Agriculture- } \\
\text { Basel }\end{array}$ & $\begin{array}{l}10.1063 / 5.001 \\
5984\end{array}$ \\
\hline \multicolumn{5}{|c|}{ Transmission of COVID-19 } \\
\hline 94 & $\begin{array}{l}\text { Modeling the role of respiratory droplets } \\
\text { in Covid-19 type pandemics }\end{array}$ & $\begin{array}{l}\text { Chaudhuri, } \\
\text { S }\end{array}$ & Phys Fluids & $\begin{array}{l}10.1063 / 5.001 \\
5984\end{array}$ \\
\hline 95 & $\begin{array}{l}\text { Persistence of SARS-CoV-2 in the } \\
\text { environment and COVID-19 } \\
\text { transmission risk from environmental } \\
\text { matrices and surfaces }\end{array}$ & Carraturo, F & $\begin{array}{l}\text { Environ } \\
\text { Pollut }\end{array}$ & $\begin{array}{l}\text { 10.1016/j.env } \\
\text { pol.2020.1150 } \\
10\end{array}$ \\
\hline 96 & $\begin{array}{l}\text { Quantifying aerosolization of facial } \\
\text { plastic surgery procedures in the } \\
\text { COVID-19 era: safety and particle } \\
\text { generation in craniomaxillofacial trauma } \\
\text { and rhinoplasty }\end{array}$ & $\begin{array}{l}\text { Gadkaree, } \\
\text { SK }\end{array}$ & $\begin{array}{l}\text { Facial Plast } \\
\text { Surg } \\
\text { Aesthetic } \\
\text { Med }\end{array}$ & $\begin{array}{l}10.1089 / \text { fpsa } \\
\mathrm{m} .2020 .0322\end{array}$ \\
\hline 97 & $\begin{array}{l}\text { Review of novel human beta- } \\
\text { coronavirus ( } 2019 \text {-nCoV or SARS- } \\
\text { CoV-2) from the food industry } \\
\text { perspective - appropriate approaches to } \\
\text { food production technology }\end{array}$ & Goli, M & $\begin{array}{l}\text { Food Sci } \\
\text { Nutr }\end{array}$ & $\begin{array}{l}10.1002 / \text { fsn } 3 . \\
1892\end{array}$ \\
\hline 98 & $\begin{array}{l}\text { Synanthropic rodents as virus reservoirs } \\
\text { and transmitters }\end{array}$ & $\begin{array}{l}\text { Gravinatti, } \\
\text { ML }\end{array}$ & $\begin{array}{l}\text { Rev Soc } \\
\text { Bras Med } \\
\text { Trop }\end{array}$ & $\begin{array}{l}10.1590 / 0037 \\
-8682-0486- \\
2019\end{array}$ \\
\hline
\end{tabular}


Table S4: Articles returned from Web of Science and reviewed for causal relations

\begin{tabular}{|c|c|c|c|c|}
\hline No. & Title & $\begin{array}{c}\text { First } \\
\text { author }\end{array}$ & Journal & DOI \\
\hline 99 & $\begin{array}{l}\text { An updated min-review on environmental } \\
\text { route of the SARS-CoV-2 transmission }\end{array}$ & $\begin{array}{l}\text { Hoseinza- } \\
\text { deh, E }\end{array}$ & $\begin{array}{l}\text { Ecotoxicol } \\
\text { Environ } \\
\text { Saf }\end{array}$ & $\begin{array}{l}10.1016 / \text { j.ec } \\
\text { oenv.2020.1 } \\
11015\end{array}$ \\
\hline 100 & $\begin{array}{l}\text { Anthropogenic gadolinium in freshwater } \\
\text { and drinking water systems }\end{array}$ & Brunjes, R & Water Res & $\begin{array}{l}10.1016 / j . w \\
\text { atres.2020.1 } \\
15966\end{array}$ \\
\hline 101 & $\begin{array}{l}\text { Assuring food security in Singapore, a small } \\
\text { island state facing COVID-19 }\end{array}$ & Teng, $\mathrm{P}$ & $\begin{array}{l}\text { Food } \\
\text { Secur }\end{array}$ & $\begin{array}{l}10.1007 / \mathrm{s} 12 \\
571-020- \\
01077-0\end{array}$ \\
\hline 102 & $\begin{array}{l}\text { Baby pangolins on my plate: possible } \\
\text { lessons to learn from the COVID-19 } \\
\text { pandemic }\end{array}$ & Volpato, G & $\begin{array}{l}\text { J } \\
\text { Ethnobiol } \\
\text { Ethnomed }\end{array}$ & $\begin{array}{l}10.1186 / \mathrm{s} 13 \\
002-020- \\
00366-4\end{array}$ \\
\hline 103 & $\begin{array}{l}\text { Can the coronavirus disease be transmitted } \\
\text { from food? A review of evidence, risks, } \\
\text { policies and knowledge gaps }\end{array}$ & Han, J & $\begin{array}{l}\text { Environ } \\
\text { Chem Lett }\end{array}$ & $\begin{array}{l}10.1007 / \mathrm{s} 10 \\
311-020- \\
01101-\mathrm{x}\end{array}$ \\
\hline 104 & $\begin{array}{l}\text { Challenges of COVID-19 in children in } \\
\text { low- and middle-income countries }\end{array}$ & Zar, HJ & $\begin{array}{l}\text { Paediatr } \\
\text { Respir } \\
\text { Rev }\end{array}$ & $\begin{array}{l}10.1016 / \mathrm{j} . \mathrm{pr} \\
\text { rv.2020.06.0 } \\
16\end{array}$ \\
\hline 105 & $\begin{array}{l}\text { Changes in weight and nutritional habits in } \\
\text { adults with obesity during the lockdown } \\
\text { period caused by the COVID-19 virus } \\
\text { emergency }\end{array}$ & $\begin{array}{l}\text { Pellegrini, } \\
\mathrm{M}\end{array}$ & Nutrients & $\begin{array}{l}10.3390 / \text { nu1 } \\
2072016\end{array}$ \\
\hline 106 & $\begin{array}{l}\text { Cleaning the River Ganga: impact of } \\
\text { lockdown on water quality and future } \\
\text { implications on river rejuvenation strategies }\end{array}$ & Dutta, V & $\begin{array}{l}\text { Sci Total } \\
\text { Environ }\end{array}$ & $\begin{array}{l}10.1016 / j . s c \\
\text { itotenv.2020 } \\
.140756\end{array}$ \\
\hline 107 & $\begin{array}{l}\text { Communicable diseases (including COVID- } \\
\text { 19) - induced global depression: caused by } \\
\text { inadequate healthcare expenditures, } \\
\text { population density, and mass panic }\end{array}$ & Anser, MK & $\begin{array}{l}\text { Front } \\
\text { Public } \\
\text { Health }\end{array}$ & $\begin{array}{l}10.3389 / \mathrm{fpu} \\
\text { bh.2020.003 } \\
98\end{array}$ \\
\hline 108 & $\begin{array}{l}\text { Computational analysis of SARS-CoV- } \\
\text { 2/COVID-19 surveillance by wastewater- } \\
\text { based epidemiology locally and globally: } \\
\text { feasibility, economy, opportunities and } \\
\text { challenges }\end{array}$ & Hart, OE & $\begin{array}{l}\text { Sci Total } \\
\text { Environ }\end{array}$ & $\begin{array}{l}10.1016 / j . s c \\
\text { itotenv. } 2020 \\
.138875\end{array}$ \\
\hline 109 & $\begin{array}{l}\text { Coronavirus } 2019 \text { and health systems } \\
\text { affected by protracted conflict: the case of } \\
\text { Syria }\end{array}$ & Abbara, A & $\begin{array}{l}\text { Int J Infect } \\
\text { Dis }\end{array}$ & $\begin{array}{l}\text { 10.1016/j.iji } \\
\text { d.2020.05.0 } \\
03\end{array}$ \\
\hline 110 & $\begin{array}{l}\text { Coronavirus disease (COVID-19) and } \\
\text { immunity booster green foods: a mini } \\
\text { review }\end{array}$ & Arshad, MS & $\begin{array}{l}\text { Food Sci } \\
\text { Nutr }\end{array}$ & $\begin{array}{l}10.1002 / \mathrm{fsn} \\
3.1719\end{array}$ \\
\hline 111 & $\begin{array}{l}\text { COVID-19 (SARS-CoV-2) pandemic: fears, } \\
\text { facts and preventive measures }\end{array}$ & $\begin{array}{l}\text { Ayenig- } \\
\text { bara, IO }\end{array}$ & Germs & $\begin{array}{l}10.18683 / \mathrm{ge} \\
\mathrm{rms} .2020 .12 \\
08\end{array}$ \\
\hline
\end{tabular}


Table S4: Articles returned from Web of Science and reviewed for causal relations (cont'd)

\begin{tabular}{|c|c|c|c|c|}
\hline No. & Title & First author & Journal & DOI \\
\hline 112 & $\begin{array}{l}\text { Covid-19 and dietary socioecology: risk } \\
\text { minimisation }\end{array}$ & Watanabe, S & $\begin{array}{l}\text { Asia Pac J } \\
\text { Clin Nutr }\end{array}$ & $\begin{array}{r}10.6133 / \mathrm{ap} \\
\text { jen.202007 } \\
29(2) .000\end{array}$ \\
\hline 113 & $\begin{array}{l}\text { COVID-19 and food and nutritional (in) } \\
\text { security: action by the Brazilian Federal } \\
\text { Government during the pandemic, with } \\
\text { budget cuts and institutional dismantlement }\end{array}$ & Alpino, TDA & $\begin{array}{l}\text { Cad Saude } \\
\text { Publica }\end{array}$ & $\begin{array}{l}10.1590 / 01 \\
02- \\
311 \times 00161 \\
320\end{array}$ \\
\hline 114 & $\begin{array}{l}\text { COVID-19 and labour in agriculture: } \\
\text { Economic and productive impacts in an } \\
\text { agricultural area of the Mediterranean }\end{array}$ & Cortignani, $\mathrm{R}$ & $\begin{array}{l}\text { Ital J } \\
\text { Agron }\end{array}$ & $\begin{array}{l}10.4081 / \mathrm{ija} \\
.2020 .1653\end{array}$ \\
\hline 115 & $\begin{array}{l}\text { COVID-19 and quarantine orders: A } \\
\text { practical approach }\end{array}$ & Botes, WM & $\begin{array}{l}\text { SAMJ S } \\
\text { Afr Med J }\end{array}$ & $\begin{array}{l}10.7196 / \mathrm{S} \\
\text { AMJ.2020. } \\
\text { v110i6.147 } \\
94\end{array}$ \\
\hline 116 & $\begin{array}{l}\text { Covid-19 and spatial planning A few issues } \\
\text { concerning public policy }\end{array}$ & Lai, S & $\begin{array}{l}\text { TeMA J } \\
\text { Land Use } \\
\text { Mob } \\
\text { Environ }\end{array}$ & $\begin{array}{l}10.6092 / 19 \\
70- \\
9870 / 6846\end{array}$ \\
\hline 117 & $\begin{array}{l}\text { COVID- } 19 \text { and surface water quality: } \\
\text { improved lake water quality during the } \\
\text { lockdown }\end{array}$ & Yunus, AP & $\begin{array}{l}\text { Sci Total } \\
\text { Environ }\end{array}$ & $\begin{array}{l}10.1016 / j . s \\
\text { citotenv.20 } \\
20.139012\end{array}$ \\
\hline 118 & $\begin{array}{l}\text { COVID- } 19 \text { and the Rohingya refugees in } \\
\text { Bangladesh: the challenges and } \\
\text { recommendations }\end{array}$ & Islam, MN & $\begin{array}{l}\text { Asia Pac J } \\
\text { Public } \\
\text { Health }\end{array}$ & $\begin{array}{l}10.1177 / 10 \\
105395209 \\
32707\end{array}$ \\
\hline 119 & $\begin{array}{l}\text { COVID-19 lockdown measures reveal } \\
\text { human impact on water transparency in the } \\
\text { Venice Lagoon }\end{array}$ & Braga, F & $\begin{array}{l}\text { Sci Total } \\
\text { Environ }\end{array}$ & $\begin{array}{l}10.1016 / \mathrm{j} . \mathrm{s} \\
\text { citotenv.20 } \\
20.139612\end{array}$ \\
\hline 120 & $\begin{array}{l}\text { COVID-19 pandemic and lockdown: cause } \\
\text { of sleep disruption, depression, somatic } \\
\text { pain, and increased screen exposure of } \\
\text { office workers and students of India }\end{array}$ & Majumdar, P & $\begin{array}{l}\text { Chronobiol } \\
\text { Int }\end{array}$ & $\begin{array}{l}10.1080 / 07 \\
420528.20 \\
20.178610 \\
7\end{array}$ \\
\hline 121 & $\begin{array}{l}\text { COVID- } 19 \text { pandemic and mitigation } \\
\text { strategies: implications for maternal and } \\
\text { child health and nutrition }\end{array}$ & Akseer, N & $\begin{array}{l}\text { Am J Clin } \\
\text { Nutr }\end{array}$ & $\begin{array}{l}\text { 10.1093/ajc } \\
\mathrm{n} / \mathrm{nqaa} 171\end{array}$ \\
\hline 122 & $\begin{array}{l}\text { COVID-19 pandemic and Rohingya } \\
\text { refugees in Bangladesh: What are the } \\
\text { major concerns? }\end{array}$ & Banik, R & $\begin{array}{l}\text { Glob } \\
\text { Public } \\
\text { Health }\end{array}$ & $\begin{array}{l}10.1080 / 17 \\
441692.20 \\
20.181210 \\
3\end{array}$ \\
\hline 123 & $\begin{array}{l}\text { Covid- } 19 \text {, environmental engineering and } \\
\text { the end of the world as we know it }\end{array}$ & $\begin{array}{l}\text { Pawlowski, } \\
\text { A }\end{array}$ & $\begin{array}{l}\text { Probl } \\
\text { Ekoroz- } \\
\text { woju }\end{array}$ & \\
\hline
\end{tabular}


Table S4: Articles returned from Web of Science and reviewed for causal relations (cont'd)

\begin{tabular}{|c|c|c|c|c|}
\hline No. & $\begin{array}{c}\text { Title } \\
\end{array}$ & First author & Journal & DOI \\
\hline 124 & $\begin{array}{l}\text { COVID-19: socio-environmental } \\
\text { challenges of Rohingya refugees in } \\
\text { Bangladesh }\end{array}$ & Shammi, M & $\begin{array}{l}\text { J Environ } \\
\text { Health Sci } \\
\text { Eng }\end{array}$ & $\begin{array}{l}10.1007 / \mathrm{s} 40 \\
201-020- \\
00489-6\end{array}$ \\
\hline 125 & $\begin{array}{l}\text { Covid19 pandemic as a further driver } \\
\text { of water scarcity in Africa }\end{array}$ & Boretti, A & GeoJournal & $\begin{array}{l}10.1007 / \mathrm{s} 10 \\
708-020- \\
10280-7\end{array}$ \\
\hline 126 & $\begin{array}{l}\text { Dietary choices and habits during } \\
\text { COVID-19 lockdown: experience from } \\
\text { Poland }\end{array}$ & Sidor, A & Nutrients & $\begin{array}{l}10.3390 / \text { nul } \\
2061657\end{array}$ \\
\hline 127 & $\begin{array}{l}\text { Diversified farms facing the Covid-19 } \\
\text { pandemic: first signals from Italian } \\
\text { case studies }\end{array}$ & $\begin{array}{l}\text { Mastronardi, } \\
\text { L }\end{array}$ & Sustainability & $\begin{array}{l}10.3390 / \mathrm{su} 1 \\
2145709\end{array}$ \\
\hline 128 & $\begin{array}{l}\text { Effect of heat and humidity on the } \\
\text { incidence and mortality due to COVID- } \\
19 \text { pandemic in European countries }\end{array}$ & Meo, SA & $\begin{array}{l}\text { Eur Rev Med } \\
\text { Pharmacol Sci }\end{array}$ & $\begin{array}{l}10.26355 / \mathrm{eu} \\
\text { rrev_202009 } \\
22874\end{array}$ \\
\hline 129 & $\begin{array}{l}\text { Effects of COVID-19 home } \\
\text { confinement on eating behaviour and } \\
\text { physical activity: results of the ECLB- } \\
\text { COVID19 international online survey }\end{array}$ & Ammar, A & Nutrients & $\begin{array}{l}10.3390 / \mathrm{nu} 1 \\
2061583\end{array}$ \\
\hline 130 & $\begin{array}{l}\text { Fast deployment of COVID-19 } \\
\text { disinfectant from common ethanol of } \\
\text { gas stations in Brazil }\end{array}$ & Itiki, R & $\begin{array}{l}\text { Health Policy } \\
\text { Technol }\end{array}$ & $\begin{array}{l}10.1016 / j . h 1 \\
\text { pt.2020.07.0 } \\
02\end{array}$ \\
\hline 131 & $\begin{array}{l}\text { Frequent hand washing for COVID- } 19 \\
\text { prevention can cause hand dermatitis: } \\
\text { management tips }\end{array}$ & Beiu, C & Cureus & $\begin{array}{l}10.7759 / \text { cur } \\
\text { eus. } 7506\end{array}$ \\
\hline 132 & $\begin{array}{l}\text { Hand hygiene among health care } \\
\text { workers during COVID- } 19 \text { pandemic: } \\
\text { challenges and recommendations }\end{array}$ & Araghi, F & Dermatitis & $\begin{array}{l}10.1097 / \mathrm{DE} \\
\text { R.00000000 } \\
00000639\end{array}$ \\
\hline 133 & $\begin{array}{l}\text { Home gardening and urban agriculture } \\
\text { for advancing food and nutritional } \\
\text { security in response to the COVID-19 } \\
\text { pandemic }\end{array}$ & Lal, R & Food Secur & $\begin{array}{l}10.1007 / \mathrm{s} 12 \\
571-020- \\
01058-3\end{array}$ \\
\hline 134 & $\begin{array}{l}\text { How health inequality affect responses } \\
\text { to the COVID-19 pandemic in Sub- } \\
\text { Saharan Africa }\end{array}$ & Okoi, O & World Dev & $\begin{array}{l}\text { 10.1016/j.w } \\
\text { orlddev.202 } \\
0.105067\end{array}$ \\
\hline 135 & $\begin{array}{l}\text { How Indian agriculture should change } \\
\text { after COVID-19 }\end{array}$ & Kumar, A & Food Secur & $\begin{array}{l}10.1007 / \mathrm{s} 12 \\
571-020- \\
01063-6\end{array}$ \\
\hline 136 & $\begin{array}{l}\text { ICT, social media and COVID-19: } \\
\text { evidence from informal home-based } \\
\text { business community in Kuwait City }\end{array}$ & Saleh, Y & $\begin{array}{l}\text { J Enterprising } \\
\text { Communities } \\
\text { People Places } \\
\text { Global Econ }\end{array}$ & $\begin{array}{l}\text { 10.1108/JE } \\
\text { C-07-2020- } \\
0131\end{array}$ \\
\hline
\end{tabular}


Table S4: Articles returned from Web of Science and reviewed for causal relations (cont'd)

\begin{tabular}{|c|c|c|c|c|}
\hline No. & Title & First author & Journal & DOI \\
\hline 137 & $\begin{array}{l}\text { Impact of COVID- } 19 \text { pandemic on } \\
\text { agricultural wholesale prices in India: a } \\
\text { comparative analysis across the phases of } \\
\text { the lockdown }\end{array}$ & Ali, J & J Public Aff & $\begin{array}{l}10.1002 / \mathrm{pa} \\
2402\end{array}$ \\
\hline 138 & $\begin{array}{l}\text { Impending scope of water sanitation and } \\
\text { hygiene (WASH) in the post COVID19 } \\
\text { pandemic era: an opportunity call }\end{array}$ & Kalpana, P & $\begin{array}{l}\text { Indian J } \\
\text { Community } \\
\text { Health }\end{array}$ & \\
\hline 139 & $\begin{array}{l}\text { Imprints of pandemic lockdown on } \\
\text { subsurface water quality in the coastal } \\
\text { industrial city of Tuticorin, South India: } \\
\text { A revival perspective }\end{array}$ & Selvam, S & $\begin{array}{l}\text { Sci Total } \\
\text { Environ }\end{array}$ & $\begin{array}{l}10.1007 / \mathrm{s} 10 \\
708-020- \\
10280-7\end{array}$ \\
\hline 140 & $\begin{array}{l}\text { Indian agriculture, air pollution, and } \\
\text { public health in the age of COVID }\end{array}$ & $\begin{array}{l}\text { McDonald, } \\
\text { AJ }\end{array}$ & World Dev & $\begin{array}{l}10.3390 / \text { nu } 1 \\
2061657\end{array}$ \\
\hline 141 & $\begin{array}{l}\text { Indigenous smallholder struggles in Peru: } \\
\text { nutrition security, agrobiodiversity, and } \\
\text { food sovereignty amid transforming } \\
\text { global systems and climate change }\end{array}$ & $\begin{array}{l}\text { Zimmerer, } \\
\text { KS }\end{array}$ & $\begin{array}{l}\text { J Lat Am } \\
\text { Geogr }\end{array}$ & $\begin{array}{l}10.3390 / \mathrm{su} 1 \\
2145709\end{array}$ \\
\hline 142 & $\begin{array}{l}\text { Indirect impact of COVID- } 19 \text { on } \\
\text { environment: a brief study in Indian } \\
\text { context }\end{array}$ & $\begin{array}{l}\text { Lokhand- } \\
\text { wala, S }\end{array}$ & Environ Res & $\begin{array}{l}10.26355 / \mathrm{eu} \\
\text { rrev_202009 } \\
22874\end{array}$ \\
\hline 143 & $\begin{array}{l}\text { Individual risk management strategy and } \\
\text { potential therapeutic options for the } \\
\text { COVID-19 pandemic }\end{array}$ & Gasmi, A & $\begin{array}{l}\text { Clin } \\
\text { Immunol }\end{array}$ & $\begin{array}{l}\overline{1} 0.1016 / \mathrm{j} . \mathrm{cli} \\
\mathrm{m} .2020 .108 \\
409\end{array}$ \\
\hline 144 & $\begin{array}{l}\text { Influence of COVID-19 spread on water } \\
\text { drinking demand: the case of Puglia } \\
\text { Region (Southern Italy) }\end{array}$ & Balacco, G; & $\begin{array}{l}\text { Sustainab- } \\
\text { ility }\end{array}$ & $\begin{array}{l}10.3390 / \mathrm{su} 1 \\
2155919\end{array}$ \\
\hline 145 & Introduction to modern climate change & Ahmed, M & $\begin{array}{l}\text { Sci Total } \\
\text { Environ }\end{array}$ & $\begin{array}{l}10.1016 / j . s c \\
\text { itotenv. } 2020 \\
.139397\end{array}$ \\
\hline 146 & LGBTQ plus farmer health in COVID-19 & Wypler, J & $\begin{array}{l}\text { J Agromed- } \\
\text { icine }\end{array}$ & $\begin{array}{l}10.1080 / 105 \\
9924 X .2020 \\
.1814923\end{array}$ \\
\hline 147 & $\begin{array}{l}\text { Making COVID-19 prevention etiquette } \\
\text { of social distancing a reality for the } \\
\text { homeless and slum dwellers in Ghana: } \\
\text { lessons for consideration }\end{array}$ & Morgan, AK & $\begin{array}{l}\text { Local } \\
\text { Environ }\end{array}$ & $\begin{array}{l}10.1080 / 135 \\
49839.2020 . \\
1789854\end{array}$ \\
\hline 148 & $\begin{array}{l}\text { Maternal health and non-communicable } \\
\text { disease prevention: An investment case } \\
\text { for the post COVID- } 19 \text { world and need } \\
\text { for better health economic data }\end{array}$ & Kapur, A & $\begin{array}{l}\text { Int J } \\
\text { Gynaecol } \\
\text { Obstet }\end{array}$ & $\begin{array}{l}10.1002 / \mathrm{ijgo} \\
.13198\end{array}$ \\
\hline
\end{tabular}


Table S4: Articles returned from Web of Science and reviewed for causal relations (cont'd)

\begin{tabular}{|c|c|c|c|c|}
\hline No. & $\begin{array}{c}\text { Title } \\
\end{array}$ & First author & Journal & DOI \\
\hline 149 & $\begin{array}{l}\text { Measuring Italian citizens' engagement } \\
\text { in the first wave of the COVID-19 } \\
\text { pandemic containment measures: a } \\
\text { cross-sectional study }\end{array}$ & Graffigna, G & PLoS One & $\begin{array}{l}\text { 10.1371/jou } \\
\text { rnal.pone.02 } \\
38613\end{array}$ \\
\hline 150 & $\begin{array}{l}\text { Migrant workers at crossroads-the } \\
\text { Covid-19 pandemic and the migrant } \\
\text { experience in India }\end{array}$ & Suresh, R & $\begin{array}{l}\text { Soc Work } \\
\text { Public Health }\end{array}$ & $\begin{array}{l}10.1080 / 193 \\
71918.2020 . \\
1808552\end{array}$ \\
\hline 151 & $\begin{array}{l}\text { Nowhere to hide: The significant } \\
\text { impact of coronavirus disease } 2019 \\
\text { (COVID-19) measures on elite and } \\
\text { semi-elite South African athletes }\end{array}$ & Pillay, L & $\begin{array}{l}\text { J Sci Med } \\
\text { Sport }\end{array}$ & $\begin{array}{l}10.1016 / j . j \mathrm{~s} \\
\text { ams.2020.05 } \\
.016\end{array}$ \\
\hline 152 & $\begin{array}{l}\text { Pandemics and food systems-towards a } \\
\text { proactive food safety approach to } \\
\text { disease prevention \& management }\end{array}$ & Aiyar, A & Food Secur & $\begin{array}{l}10.1007 / \mathrm{s} 12 \\
571-020- \\
01074-3\end{array}$ \\
\hline 153 & $\begin{array}{l}\text { Physical activity and nutrition } \\
\text { guidelines to help with the fight against } \\
\text { COVID-19 }\end{array}$ & $\begin{array}{l}\text { Khorami- } \\
\text { pour, K }\end{array}$ & J Sports Sci & $\begin{array}{l}10.1080 / 026 \\
40414.2020 \\
1807089\end{array}$ \\
\hline 154 & $\begin{array}{l}\text { Physics-based Bathymetry and Water } \\
\text { Quality Retrieval Using PlanetScope } \\
\text { Imagery: Impacts of } 2020 \text { COVID-19 } \\
\text { Lockdown and } 2019 \text { Extreme Flood in } \\
\text { the Venice Lagoon }\end{array}$ & $\begin{array}{l}\text { Niroumand- } \\
\text { Jadidi, M }\end{array}$ & Remote Sens & $\begin{array}{l}10.3390 / \mathrm{rs} 1 \\
2152381\end{array}$ \\
\hline 155 & $\begin{array}{l}\text { Positive and Negative Changes in Food } \\
\text { Habits, Physical Activity Patterns, and } \\
\text { Weight Status during COVID-19 } \\
\text { Confinement: Associated Factors in the } \\
\text { Chilean Population }\end{array}$ & $\begin{array}{l}\text { Reyes- } \\
\text { Olavarria, D }\end{array}$ & $\begin{array}{l}\text { Int J Environ } \\
\text { Res Public } \\
\text { Health }\end{array}$ & $\begin{array}{l}10.3390 / \text { ijer } \\
\text { ph17155431 }\end{array}$ \\
\hline 156 & $\begin{array}{l}\text { Post-travel screening of symptomatic } \\
\text { and asymptomatic travelers }\end{array}$ & $\begin{array}{l}\text { Korzeniew- } \\
\text { ski, K }\end{array}$ & $\begin{array}{l}\text { Int Marit } \\
\text { Health }\end{array}$ & $\begin{array}{l}10.5603 / \mathrm{IM} \\
\text { H.2020.002 } \\
3\end{array}$ \\
\hline 157 & $\begin{array}{l}\text { Potential consequences of COVID- } 19 \\
\text { for sustainable meat consumption: the } \\
\text { role of food safety concerns and } \\
\text { responsibility attributions }\end{array}$ & Yang, XS & Br Food J & $\begin{array}{l}\text { 10.1108/BF } \\
\mathrm{J}-04-2020- \\
0332\end{array}$ \\
\hline 158 & $\begin{array}{l}\text { Resilience and Vulnerabilities of the } \\
\text { North American Food System during } \\
\text { the Covid-19 Pandemic }\end{array}$ & Orden, D & Eurochoices & $\begin{array}{l}10.1111 / 174 \\
6- \\
692 X .12273\end{array}$ \\
\hline 159 & $\begin{array}{l}\text { Review of novel human beta- } \\
\text { coronavirus (2019-nCoVorSARS-CoV- } \\
\text { 2) from the food industry perspective- } \\
\text { Food plant health principles }\end{array}$ & Goli, M & J Food Saf & $\begin{array}{l}10.1111 / \mathrm{jfs} . \\
12853\end{array}$ \\
\hline
\end{tabular}


Table S4: Articles returned from Web of Science and reviewed for causal relations (cont'd)

\begin{tabular}{|c|c|c|c|c|}
\hline No. & $\begin{array}{c}\text { Title } \\
\end{array}$ & First author & Journal & DOI \\
\hline 160 & $\begin{array}{l}\text { Review of Online Food Delivery } \\
\text { Platforms and their Impacts on } \\
\text { Sustainability }\end{array}$ & $\mathrm{Li}, \mathrm{C}$ & Sustainability & $\begin{array}{l}10.3390 / \mathrm{su} 1 \\
2145528\end{array}$ \\
\hline 161 & $\begin{array}{l}\text { Sanitizer aerosol-driven ocular surface } \\
\text { disease (SADOSD)-A COVID-19 } \\
\text { repercussion? }\end{array}$ & Shetty, R & $\begin{array}{l}\text { Indian J } \\
\text { Ophthalmol }\end{array}$ & $\begin{array}{l}\text { 10.4103/ijo. } \\
\text { IJO_1308_2 } \\
0\end{array}$ \\
\hline 162 & $\begin{array}{l}\text { SARS-CoV-2 pandemic: causes and } \\
\text { current situation, historical lessons, } \\
\text { and strategical therapeutic } \\
\text { interventions }\end{array}$ & Shereen, MA & $\begin{array}{l}\text { Biomed Res } \\
\text { Ther }\end{array}$ & $\begin{array}{l}\text { 10.15419/b } \\
\text { mrat.v7i5.60 } \\
8\end{array}$ \\
\hline 163 & $\begin{array}{l}\text { Serving up food studies online: } \\
\text { teaching about food from somewhere } \\
\text { from nowhere }\end{array}$ & Levkoe, CZ & Food Cult Soc & $\begin{array}{l}10.1080 / 155 \\
28014.2020 . \\
1754041\end{array}$ \\
\hline 164 & $\begin{array}{l}\text { Slum Health: Arresting COVID-19 } \\
\text { and Improving Well-Being in Urban } \\
\text { Informal Settlements }\end{array}$ & Corburn, J & J Urban Health & $\begin{array}{l}10.1007 / \mathrm{s} 11 \\
524-020- \\
00438-6\end{array}$ \\
\hline 165 & $\begin{array}{l}\text { Social economic impact of COVID-19 } \\
\text { outbreak in India }\end{array}$ & Kumar, MS & $\begin{array}{l}\text { Int J Pervasive } \\
\text { Comput } \\
\text { Commun }\end{array}$ & $\begin{array}{l}\text { 10.1108/IJP } \\
\text { CC-06- } \\
2020-0053\end{array}$ \\
\hline 166 & $\begin{array}{l}\text { Socially distanced school-based } \\
\text { nutrition program under COVID } 19 \text { in } \\
\text { the rural Niger Delta }\end{array}$ & Francis, NN & Extr Ind Soc & $\begin{array}{l}10.1016 / \text { j.ex } \\
\text { is. } 2020.04 .0 \\
07\end{array}$ \\
\hline 167 & $\begin{array}{l}\text { Strategies and Solutions for Team } \\
\text { Sports Athletes in Isolation due to } \\
\text { COVID-19 }\end{array}$ & Jukic, I & Sports & $\begin{array}{l}10.3390 / \text { spo } \\
\text { rts } 8040056\end{array}$ \\
\hline 168 & $\begin{array}{l}\text { Structural barriers to adhering to } \\
\text { health behaviours in the context of the } \\
\text { COVID- } 19 \text { crisis: Considerations for } \\
\text { low- and middle-income countries }\end{array}$ & Coetzee, BJ & $\begin{array}{l}\text { Glob Public } \\
\text { Health }\end{array}$ & $\begin{array}{l}10.1080 / 174 \\
41692.2020 . \\
1779331\end{array}$ \\
\hline 169 & $\begin{array}{l}\text { Sustainability and development after } \\
\text { COVID-19 }\end{array}$ & Barbier, EB & World Dev & $\begin{array}{l}10.1016 / j . w \\
\text { orlddev.202 } \\
0.105082\end{array}$ \\
\hline 170 & $\begin{array}{l}\text { The Covid- } 19 \text { pandemic effects in } \\
\text { rural areas Turning challenges into } \\
\text { opportunities for rural regeneration }\end{array}$ & de Luca, C & $\begin{array}{l}\text { TeMA J Land } \\
\text { Use Mob } \\
\text { Environ }\end{array}$ & $\begin{array}{l}10.6092 / 197 \\
0-9870 / 6844\end{array}$ \\
\hline 171 & $\begin{array}{l}\text { The Effects of COVID- } 19 \text { Pandemic } \\
\text { Outbreak on the Household Economy }\end{array}$ & Celik, B & $\begin{array}{l}\text { J Res Med } \\
\text { Dent Sci }\end{array}$ & \\
\hline 172 & $\begin{array}{l}\text { The Food Acquisition Program (PAA) } \\
\text { as a strategy to face the challenges of } \\
\text { COVID-19 }\end{array}$ & $\begin{array}{l}\text { Sambuichi, } \\
\text { RHR }\end{array}$ & $\begin{array}{l}\text { Rev De Adm } \\
\text { Publica }\end{array}$ & $\begin{array}{l}10.1590 / 003 \\
4- \\
7612202002 \\
58 x\end{array}$ \\
\hline
\end{tabular}


Table S4: Articles returned from Web of Science and reviewed for causal relations (cont'd)

\begin{tabular}{|c|c|c|c|c|}
\hline No. & Title & First author & Journal & DOI \\
\hline 173 & $\begin{array}{l}\text { The Impact of Isolation Measures Due to } \\
\text { COVID-19 on Energy Intake and } \\
\text { Physical Activity Levels in Australian } \\
\text { University Students }\end{array}$ & Gallo, LA & Nutrients & $\begin{array}{l}10.3390 / \text { nul } \\
2061865\end{array}$ \\
\hline 174 & $\begin{array}{l}\text { The impact of the Covid-19 health crisis } \\
\text { on the water cycle in France }\end{array}$ & Paplorey, C & $\begin{array}{l}\text { Houille } \\
\text { Blanche }\end{array}$ & $\begin{array}{l}10.1051 / \mathrm{lhb} / \\
2020031\end{array}$ \\
\hline 175 & $\begin{array}{l}\text { The impacts of COVID-19 measures on } \\
\text { global environment and fertility rate: } \\
\text { double coincidence }\end{array}$ & Anser, MK & $\begin{array}{l}\text { Air Qual } \\
\text { Atomos } \\
\text { Health }\end{array}$ & $\begin{array}{l}10.1007 / \mathrm{s} 11 \\
869-020- \\
00865-\mathrm{Z}\end{array}$ \\
\hline 176 & $\begin{array}{l}\text { The management of coronavirus disease } \\
2019 \text { (COVID-19) }\end{array}$ & Liu, JL & J Med Virol & $\begin{array}{l}10.1002 / \mathrm{jmv} \\
.25965\end{array}$ \\
\hline 177 & $\begin{array}{l}\text { Understanding COVID-19 transmission, } \\
\text { health impacts and mitigation: timely } \\
\text { social distancing is the key }\end{array}$ & Kaur, S & $\begin{array}{l}\text { Environ } \\
\text { Dev Sustain }\end{array}$ & $\begin{array}{l}10.1007 / \mathrm{s} 10 \\
668-020- \\
00884-\mathrm{X}\end{array}$ \\
\hline 178 & $\begin{array}{l}\text { Unlocking the impacts of COVID- } 19 \\
\text { lockdowns: changes in thermal electricity } \\
\text { generation water footprint and virtual } \\
\text { water trade in Europe }\end{array}$ & Roidt, M & $\begin{array}{l}\text { Environ Sci } \\
\text { Technol } \\
\text { Lett }\end{array}$ & $\begin{array}{l}10.1021 / \mathrm{acs} . \\
\text { estlett.0c003 } \\
81\end{array}$ \\
\hline 179 & $\begin{array}{l}\text { Wither the self-sufficiency illusion? Food } \\
\text { security in Arab Gulf States and the } \\
\text { impact of COVID-19 }\end{array}$ & Woertz, E & Food Secur & $\begin{array}{l}10.1007 / \mathrm{s} 12 \\
571-020- \\
01081-4\end{array}$ \\
\hline
\end{tabular}




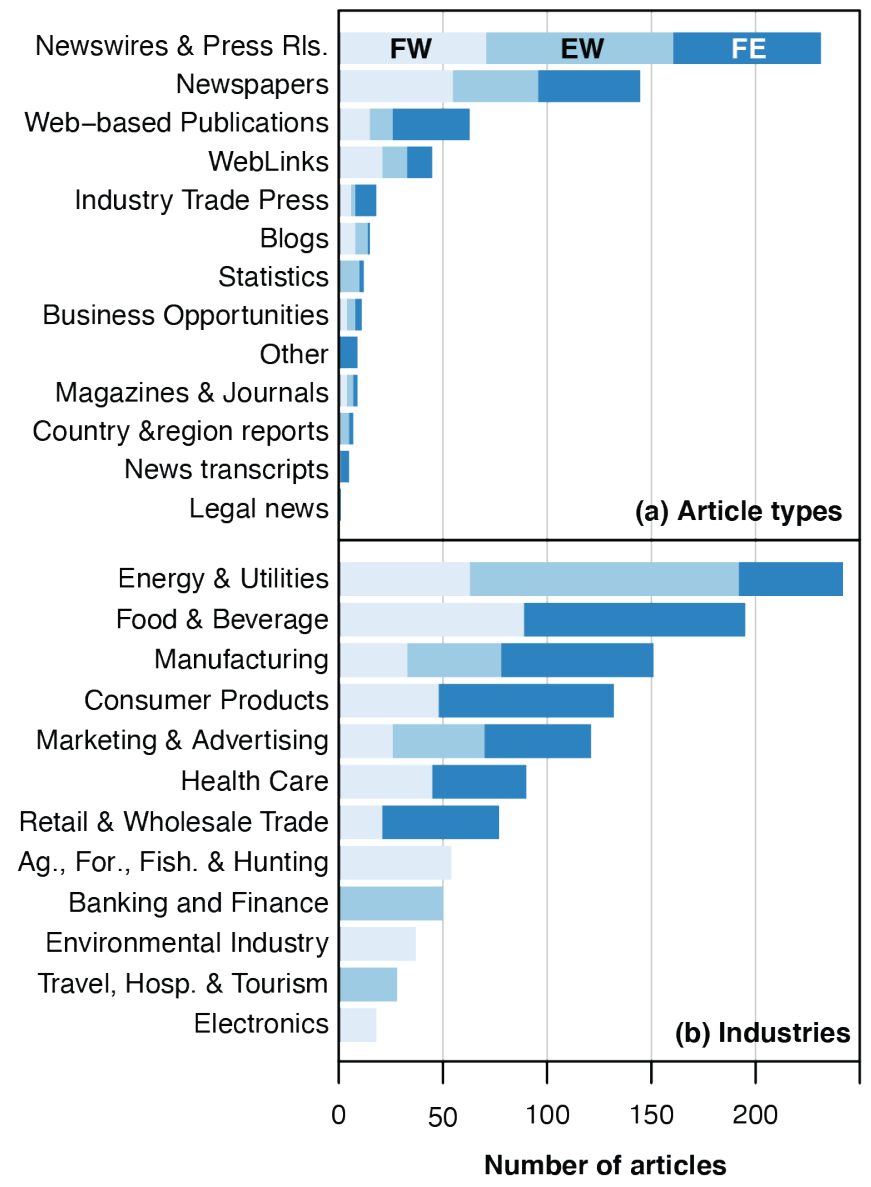

Figure S1: Distribution of news/media articles by (a) article type and (b) industry (FW = foodwater; $\mathrm{EW}=$ energy-water; $\mathrm{FE}=$ food-energy; legend at top applies throughout). Articles returned may be counted in multiple categories. 
Table S5: Summary of NexisUni search syntaxes

\begin{tabular}{|c|c|c|c|c|c|c|c|}
\hline No. & $\mathbf{F} / \mathbf{E} / \mathbf{W}^{\mathbf{a}}$ & Search terms & $\begin{array}{c}\text { Total } \\
\text { results }\end{array}$ & $\begin{array}{c}\text { English } \\
\text { results }\end{array}$ & $\begin{array}{c}\text { Intl. } \\
\text { sources }\end{array}$ & $\begin{array}{c}\text { U.S. } \\
\text { sources }\end{array}$ & $\begin{array}{l}\text { Reason for } \\
\text { exclusion }^{\mathbf{b}}\end{array}$ \\
\hline 1 & FEW & $\begin{array}{l}\text { "'COVID-19" } \\
\text { OR } \\
\text { "coronavirus"" } \\
\text { AND "'Water" } \\
\text { OR "Energy" } \\
\text { OR "Food""' }\end{array}$ & $\begin{array}{c}2,103 \\
877\end{array}$ & $2,037,851$ & $1,427,431$ & 676,446 & $\begin{array}{l}\text { many } \\
\text { irrelevant } \\
\text { artices withir } \\
\text { first page }\end{array}$ \\
\hline 2 & E & $\begin{array}{l}\text { title(COVID- } \\
\text { 19) or } \\
\text { title(coronaviru } \\
\text { s) and } \\
\text { title(energy) }\end{array}$ & 6,024 & 5,924 & 3,931 & 2,093 & $\begin{array}{l}\text { too many } \\
\text { results; many } \\
\text { not relevant } \\
\text { within first } \\
\text { two pages }\end{array}$ \\
\hline 3 & W & $\begin{array}{l}\text { title(COVID- } \\
\text { 19) or } \\
\text { title(coronaviru } \\
\text { s) and } \\
\text { title(water) }\end{array}$ & 4,940 & 4,892 & 3,329 & 1,611 & $\begin{array}{l}\text { too many } \\
\text { results; many } \\
\text { not relevant } \\
\text { within first } \\
\text { two pages }\end{array}$ \\
\hline 4 & $\mathrm{~F}$ & $\begin{array}{l}\text { title(COVID- } \\
\text { 19) or } \\
\text { title(coronaviru } \\
\text { s) and } \\
\text { title(food) }\end{array}$ & 21,330 & 20,999 & 15,064 & 6,266 & $\begin{array}{l}\text { too many } \\
\text { results; many } \\
\text { not relevant } \\
\text { within first } \\
\text { two pages }\end{array}$ \\
\hline 5 & FEW & $\begin{array}{l}\text { "coronavirus" } \\
\text { or "COVID- } \\
\text { 19" and "food" } \\
\text { and "water" } \\
\text { and "energy" }\end{array}$ & 31,611 & 31,535 & 18,182 & 13,353 & $\begin{array}{l}\text { many } \\
\text { irrelevant } \\
\text { articles } \\
\text { within first } \\
\text { page }\end{array}$ \\
\hline 6 & FEW & $\begin{array}{l}\text { title(coronaviru } \\
\text { s) or } \\
\text { title(COVID- } \\
\text { 19) and food } \\
\text { and water and } \\
\text { energy }\end{array}$ & 5,162 & 5,153 & 3,335 & 1,827 & $\begin{array}{c}\text { too many } \\
\text { results, many } \\
\text { not relvant } \\
\text { within first } 2 \\
\text { pages }\end{array}$ \\
\hline 7 & FEW & $\begin{array}{c}\text { title( } \\
\text { coronavirus) or } \\
\text { title(COVID- } \\
\text { 19) and } \\
\text { title(food) and } \\
\text { title(water) and } \\
\text { title(energy) }\end{array}$ & 0 & 0 & 0 & 0 & no results \\
\hline
\end{tabular}

${ }^{a}$ Search relevant to Food/Energy/Water component in this column

${ }^{\mathrm{b}}$ Searches 1-10 excluded; searches 11-13 included 
Table S5: Summary of NexisUni search syntaxes (cont'd) ${ }^{\mathrm{a}}$

\begin{tabular}{|c|c|c|c|c|c|c|c|}
\hline No. & $\mathbf{F} / \mathbf{E} / \mathbf{W}$ & Search terms & $\begin{array}{c}\text { Total } \\
\text { results }\end{array}$ & $\begin{array}{l}\text { English } \\
\text { results }\end{array}$ & $\begin{array}{c}\text { Intl. } \\
\text { sources }\end{array}$ & $\begin{array}{c}\text { U.S. } \\
\text { sources }\end{array}$ & $\begin{array}{l}\text { Reason for } \\
\text { exclusion }\end{array}$ \\
\hline 8 & $\mathrm{FW}$ & $\begin{array}{l}\text { title(coronavirus) or } \\
\text { title(COVID-19) and } \\
\text { title(food) and } \\
\text { title(water) }\end{array}$ & 143 & 143 & 104 & 38 & $\begin{array}{c}\text { Included in } \\
\text { Search } 10\end{array}$ \\
\hline 9 & EW & $\begin{array}{l}\text { title(coronavirus) or } \\
\text { title(COVID-19) and } \\
\text { title(energy) and } \\
\text { title(water) }\end{array}$ & 44 & 44 & 28 & 16 & $\begin{array}{l}\text { Included in } \\
\text { Search } 11\end{array}$ \\
\hline 10 & $\mathrm{FE}$ & $\begin{array}{l}\text { title(coronavirus) or } \\
\text { title(COVID-19) and } \\
\text { title(energy) and } \\
\text { title(food) }\end{array}$ & 48 & 48 & 26 & 22 & $\begin{array}{l}\text { Included in } \\
\text { Search } 12\end{array}$ \\
\hline 11 & $\mathrm{FW}$ & $\begin{array}{l}\text { title(coronavirus) or } \\
\text { title(COVID*) or title( } \\
\text { SARS-CoV-2) and } \\
\text { title(food) or title( } \\
\text { nutrition*) or title( } \\
\text { hunger*) or title( crop*) } \\
\text { or title( agricultur*) and } \\
\text { title( water) or } \\
\text { title(irrigat*) }\end{array}$ & 184 & 184 & 133 & 51 & $\begin{array}{c}\mathrm{n} / \mathrm{a} \\
\text { (Included) }\end{array}$ \\
\hline 12 & EW & $\begin{array}{l}\text { title(coronavirus) or } \\
\text { title(COVID*) or title( } \\
\text { SARS-CoV-2) and } \\
\text { title(energy) or title ( } \\
\text { electri*) or title(heat*) } \\
\text { or title(conditioning) or } \\
\text { title(conditioner) and } \\
\text { title(water) or } \\
\text { title(irrigat*) }\end{array}$ & 185 & 184 & 113 & 72 & $\begin{array}{c}\mathrm{n} / \mathrm{a} \\
\text { (Included) }\end{array}$ \\
\hline 13 & $\mathrm{FE}$ & $\begin{array}{l}\text { title(coronavirus) or } \\
\text { title(COVID*) or title( } \\
\text { SARS-CoV-2) and } \\
\text { title(food) or title( } \\
\text { nutrition*) or title( } \\
\text { hunger*) or title( crop*) } \\
\text { or title( agricultur*) and } \\
\text { title( energy) or title ( } \\
\text { electri*) or title(heat*) } \\
\text { or title(conditioning) or } \\
\text { title(conditioner) }\end{array}$ & 203 & 201 & 153 & 50 & $\begin{array}{c}\mathrm{n} / \mathrm{a} \\
\text { (Included) }\end{array}$ \\
\hline
\end{tabular}


Table S6: Summary of causal relations with articles invoking each

\begin{tabular}{|c|c|c|c|}
\hline Causal relation & $\mathbf{F} / \mathbf{E} / \mathbf{W}^{\mathbf{a}}$ & $\begin{array}{c}\text { No. of news/media } \\
\text { articles invoking } \\
\text { relation }\end{array}$ & $\begin{array}{l}\text { Journal articles invoking } \\
\text { relation (from Table S4) }\end{array}$ \\
\hline \multicolumn{4}{|c|}{ Relations identified in scientific literature (solid lines in Figure 1) } \\
\hline $\begin{array}{c}\text { SARS-CoV-2 transmission } \\
\rightarrow \text { COVID- } 19 \\
\text { mortality/morbidity }\end{array}$ & & 41 & $\begin{array}{l}101,104,107,114,115,118 \\
123,124,126,127,129,134 \\
135,136,137,138,143,144 \\
146,148,150,151,158,161 \\
162,164,165,166,168,171 \\
173,174,176,178,179\end{array}$ \\
\hline $\begin{array}{c}\text { testing } \rightarrow \text { SARS-CoV-2 } \\
\text { transmission }\end{array}$ & & 51 & $\begin{array}{l}101,104,105,107,110,111 \\
112,113,114,118,121,124 \\
126,129,133,134,135,137 \\
138,141,143,147,148,155 \\
158,159,160,164,165,168 \\
173,176,179\end{array}$ \\
\hline $\begin{array}{c}\text { hand washing } \rightarrow \text { SARS- } \\
\text { CoV-2 transmission }\end{array}$ & & 16 & $\begin{array}{l}101,104,111,114,115,118 \\
123,124,126,127,131,134 \\
135,136,137,150,151,158 \\
161,162,164,165,166,171 \\
173\end{array}$ \\
\hline $\begin{array}{c}\text { physical distancing } \rightarrow \\
\text { SARS-CoV-2 transmission }\end{array}$ & & 17 & $\begin{array}{l}104,111,115,118,124,126 \\
129,138,144,146,147,156 \\
161,164,165,168,173,176 \\
177,178\end{array}$ \\
\hline $\begin{array}{l}\text { physical distancing } \rightarrow \\
\text { psychosocial harm }\end{array}$ & & 3 & $\begin{array}{l}104,105,110,112,115,120 \\
121,126,129,133,143,148 \\
151,155,162,167,170,171 \\
176,179\end{array}$ \\
\hline $\begin{array}{l}\text { physical distancing } \rightarrow \\
\text { employment/economic } \\
\text { activity }\end{array}$ & & 11 & $\begin{array}{l}101,114,115,123,124,126 \\
127,135,136,137,150,151 \\
158,162,165,166,171,173\end{array}$ \\
\hline $\begin{array}{c}\text { COVID-19 } \\
\text { mortality/morbidity } \rightarrow \\
\text { comorbidities }\end{array}$ & & 11 & $\begin{array}{l}105,113,114,121,124,133 \\
137,141,144,148,160,168\end{array}$ \\
\hline $\begin{array}{c}\text { COVID-19 } \\
\text { mortality/morbidity } \\
\text { burden of disease }\end{array}$ & & 18 & $\begin{array}{l}101,113,118,121,124,133 \\
143,164,168,176,179\end{array}$ \\
\hline $\begin{array}{c}\text { psychosocial harm } \rightarrow \text { burden } \\
\text { of disease }\end{array}$ & & 17 & $\begin{array}{l}101,105,118,126,129,148 \\
155,158,168,179\end{array}$ \\
\hline $\begin{array}{l}\text { economic support } \rightarrow \\
\text { purchasing power }\end{array}$ & & 17 & $\begin{array}{l}107,124,126,135,137,165 \\
168,179\end{array}$ \\
\hline
\end{tabular}

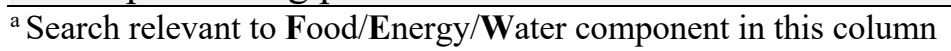


Table S6: Summary of causal relations with articles invoking each (cont'd)

\begin{tabular}{|c|c|c|c|}
\hline Causal relation & $\mathbf{F} / \mathbf{E} / \mathbf{W}^{\mathbf{a}}$ & $\begin{array}{c}\text { No. of news/media } \\
\text { articles invoking } \\
\text { relation }\end{array}$ & $\begin{array}{c}\text { Journal articles } \\
\text { invoking relation } \\
\text { (from Table S4) }\end{array}$ \\
\hline \multicolumn{4}{|c|}{ Relations identified in scientific literature (solid lines in Figure 1) (cont'd) } \\
\hline $\begin{array}{c}\text { food/nutrition security/choices } \rightarrow \\
\text { comorbidities }\end{array}$ & $\mathrm{F}$ & 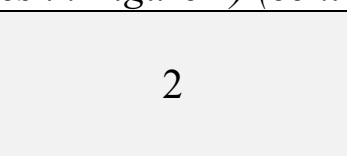 & $\begin{array}{l}110,112,121,126, \\
129,133,143,148, \\
176,179\end{array}$ \\
\hline comorbidities $\rightarrow$ burden of disease & & 1 & $\begin{array}{l}105,124,126,129, \\
143,148,155,168, \\
176\end{array}$ \\
\hline $\begin{array}{l}\text { food supply } \rightarrow \text { SARS-CoV-2 } \\
\text { transmission }\end{array}$ & $\mathrm{F}$ & 6 & $\begin{array}{l}102,103,135,152 \\
157,158,162\end{array}$ \\
\hline $\begin{array}{l}\text { purchasing power } \rightarrow \text { food/nutrition } \\
\text { security/choices }\end{array}$ & $\mathrm{F}$ & 17 & $\begin{array}{l}101,118,126,148 \\
158,168,179\end{array}$ \\
\hline $\begin{array}{c}\text { comorbidities } \rightarrow \text { COVID-19 } \\
\text { mortality/morbidity }\end{array}$ & & 11 & $\begin{array}{l}101,124,143,148 \\
168,176,179\end{array}$ \\
\hline physical distancing $\rightarrow$ food supply & $\mathrm{F}$ & 11 & $\begin{array}{l}113,114,121,133 \\
137,141,160\end{array}$ \\
\hline $\begin{array}{c}\text { waterborne pathogens } \rightarrow \\
\text { comorbidities }\end{array}$ & $\mathrm{W}$ & 3 & $\begin{array}{l}118,124,138,147, \\
164,168\end{array}$ \\
\hline $\begin{array}{c}\text { food supply } \rightarrow \text { food/nutrition } \\
\text { security/choices }\end{array}$ & $\mathrm{F}$ & 14 & $\begin{array}{l}101,113,121,133 \\
179\end{array}$ \\
\hline $\begin{array}{c}\text { comorbidities } \rightarrow \text { SARS-CoV-2 } \\
\text { transmission }\end{array}$ & & 0 & $\begin{array}{l}110,112,122,140, \\
153\end{array}$ \\
\hline \multirow{2}{*}{$\begin{array}{c}\text { water availability } \rightarrow \text { hand washing } \\
\text { employment/economic activity } \rightarrow \\
\text { purchasing power }\end{array}$} & W & 10 & $104,134,138,164$ \\
\hline & & 4 & $107,115,137,158$ \\
\hline \multirow{2}{*}{$\begin{array}{l}\text { hand washing } \rightarrow \text { comorbidities } \\
\text { SARS-CoV-2 transmission } \rightarrow \text { food } \\
\text { supply }\end{array}$} & $\mathrm{W}$ & 1 & $130,131,132,161$ \\
\hline & $\mathrm{F}$ & 3 & $113,144,146$ \\
\hline \multirow{3}{*}{$\begin{array}{c}\text { physical distancing } \rightarrow \text { water demand } \\
\text { physical distancing } \rightarrow \text { comorbidities } \\
\text { employment/economic activity } \rightarrow \\
\text { water quality }\end{array}$} & $\mathrm{W}$ & 3 & $144,146,178$ \\
\hline & & 1 & $120,153,167$ \\
\hline & W & 0 & $106,117,142$ \\
\hline physical distancing $\rightarrow$ water quality & $\mathrm{W}$ & 0 & $119,139,154$ \\
\hline \multirow{2}{*}{$\begin{array}{c}\text { physical distancing } \rightarrow \text { comorbidities } \\
\text { physical distancing } \rightarrow \text { physical } \\
\text { activity }\end{array}$} & & 1 & $120,153,167$ \\
\hline & & 0 & $129,143,173$ \\
\hline \multirow{4}{*}{$\begin{array}{c}\text { water availability } \rightarrow \text { food supply } \\
\text { physical activity } \rightarrow \text { comorbidities } \\
\text { water demand } \rightarrow \text { water availability } \\
\text { SARS-CoV-2 transmission } \rightarrow \\
\text { food/nutrition choices/security }\end{array}$} & $\mathrm{F} / \mathrm{W}$ & 6 & 101,179 \\
\hline & & 0 & 129,143 \\
\hline & $\mathrm{W}$ & 0 & 144 \\
\hline & $\mathrm{F}$ & & 157 \\
\hline
\end{tabular}

${ }^{a}$ Search relevant to Food/Energy/Water component in this column 
Table S6: Summary of causal relations with articles invoking each (cont'd)

\begin{tabular}{|c|c|c|c|}
\hline Causal relation & $\mathbf{F} / \mathbf{E} / \mathbf{W}^{\mathbf{a}}$ & $\begin{array}{c}\text { No. of news/media } \\
\text { articles invoking } \\
\text { relation }\end{array}$ & $\begin{array}{c}\text { Journal articles } \\
\text { invoking relation } \\
\text { (from Table S4) }\end{array}$ \\
\hline \multicolumn{4}{|c|}{ Relations not identified in scientific literature (dashed lines in Figure 1) } \\
\hline purchasing power $\rightarrow$ water security & $\mathrm{W}$ & 12 & \\
\hline purchasing power $\rightarrow$ energy security & E & 8 & \\
\hline $\begin{array}{l}\text { economic support } \rightarrow \text { physical } \\
\text { distancing }\end{array}$ & & 4 & \\
\hline water security $\rightarrow$ physical distancing & W & 3 & \\
\hline hand washing $\rightarrow$ physical distancing & $\mathrm{W}$ & 2 & \\
\hline water demand $\rightarrow$ waterborne pathogens & $\mathrm{W}$ & 2 & \\
\hline $\begin{array}{c}\text { economic support } \rightarrow \\
\text { employment/economic activity }\end{array}$ & & 2 & \\
\hline physical distancing $\rightarrow$ hand washing & W & 1 & \\
\hline physical distancing $\rightarrow$ energy demand & $\mathrm{E}$ & 1 & \\
\hline masks $\rightarrow$ SARS-CoV-2 transmission ${ }^{b}$ & & 1 & \\
\hline water availability $\rightarrow$ water security & W & 1 & \\
\hline energy demand $\rightarrow$ energy security & $\mathrm{E}$ & 0 & \\
\hline energy security $\rightarrow$ comorbidities & E & 0 & \\
\hline \multicolumn{4}{|l|}{ Relations omitted from Figure 1 for clarity } \\
\hline air pollution $\rightarrow$ comorbidities & & 0 & 140 \\
\hline burning ag fields $\rightarrow$ air pollution & $\mathrm{F}$ & 0 & 140 \\
\hline $\begin{array}{c}\text { food/nutrition security/choices } \rightarrow \\
\text { environment }\end{array}$ & F & 0 & 157 \\
\hline $\begin{array}{c}\text { SARS-CoV-2 transmission } \rightarrow \\
\text { commodities prices }\end{array}$ & & 0 & 137 \\
\hline $\begin{array}{l}\text { health engagement } \rightarrow \text { SARS-CoV-2 } \\
\text { transmission }\end{array}$ & & 0 & 149 \\
\hline $\begin{array}{c}\text { health engagement } \rightarrow \\
\text { employment/economic activity }\end{array}$ & & 0 & 149 \\
\hline ethanol $\rightarrow$ hand washing & W & 0 & 130 \\
\hline healthcare system $\rightarrow$ water quality & $\mathrm{W}$ & 0 & 100 \\
\hline $\begin{array}{c}\text { economic support } \rightarrow \text { resources for } \\
\text { development }\end{array}$ & & 0 & 125 \\
\hline physical distancing $\rightarrow$ fertility rates & & 0 & 175 \\
\hline physical distancing $\rightarrow$ environment & & 0 & 175 \\
\hline conflict $\rightarrow$ SARS-CoV-2 transmission & & 0 & 109 \\
\hline $\begin{array}{l}\text { health systems management } \rightarrow \text { SARS- } \\
\text { CoV-2 transmission }\end{array}$ & & 0 & 109 \\
\hline
\end{tabular}

${ }^{a}$ Search relevant to Food/Energy/Water component in this column

${ }^{\mathrm{b}}$ Grouped with testing, contact tracing and housing/shelter (solid lines) in Figure 1 
Table S6: Summary of causal relations with articles invoking each (cont'd)

\begin{tabular}{|c|c|c|c|}
\hline Causal relation & $\mathbf{F} / \mathbf{E} / \mathbf{W}^{\mathbf{a}}$ & $\begin{array}{l}\text { No. of news/media } \\
\text { articles invoking } \\
\text { relation }\end{array}$ & $\begin{array}{c}\text { Journal articles } \\
\text { invoking relation } \\
\text { (from Table S4) }\end{array}$ \\
\hline \multicolumn{4}{|c|}{ Relations omitted from Figure 1 for clarity (cont'd) } \\
\hline $\begin{array}{c}\text { natural disasters } \rightarrow \text { burden of } \\
\text { disease }\end{array}$ & & 0 & 124 \\
\hline physical distancing $\rightarrow$ fines & & 0 & 115 \\
\hline fines $\rightarrow$ purchasing power & & 0 & 115 \\
\hline $\begin{array}{c}\text { physical distancing } \rightarrow \text { educational } \\
\text { outcomes }\end{array}$ & & 0 & 166 \\
\hline $\begin{array}{c}\text { weather } \rightarrow \text { SARS-CoV-2 } \\
\text { transmission }\end{array}$ & & 0 & 128 \\
\hline $\begin{array}{c}\text { weather } \rightarrow \text { COVID-19 } \\
\text { mortality/morbidity }\end{array}$ & & 0 & 128 \\
\hline $\begin{array}{c}\text { identity inequality } \rightarrow \text { SARS-CoV-2 } \\
\text { transmission }\end{array}$ & & 0 & 146 \\
\hline
\end{tabular}

${ }^{a}$ Search relevant to Food/Energy/Water component in this column 


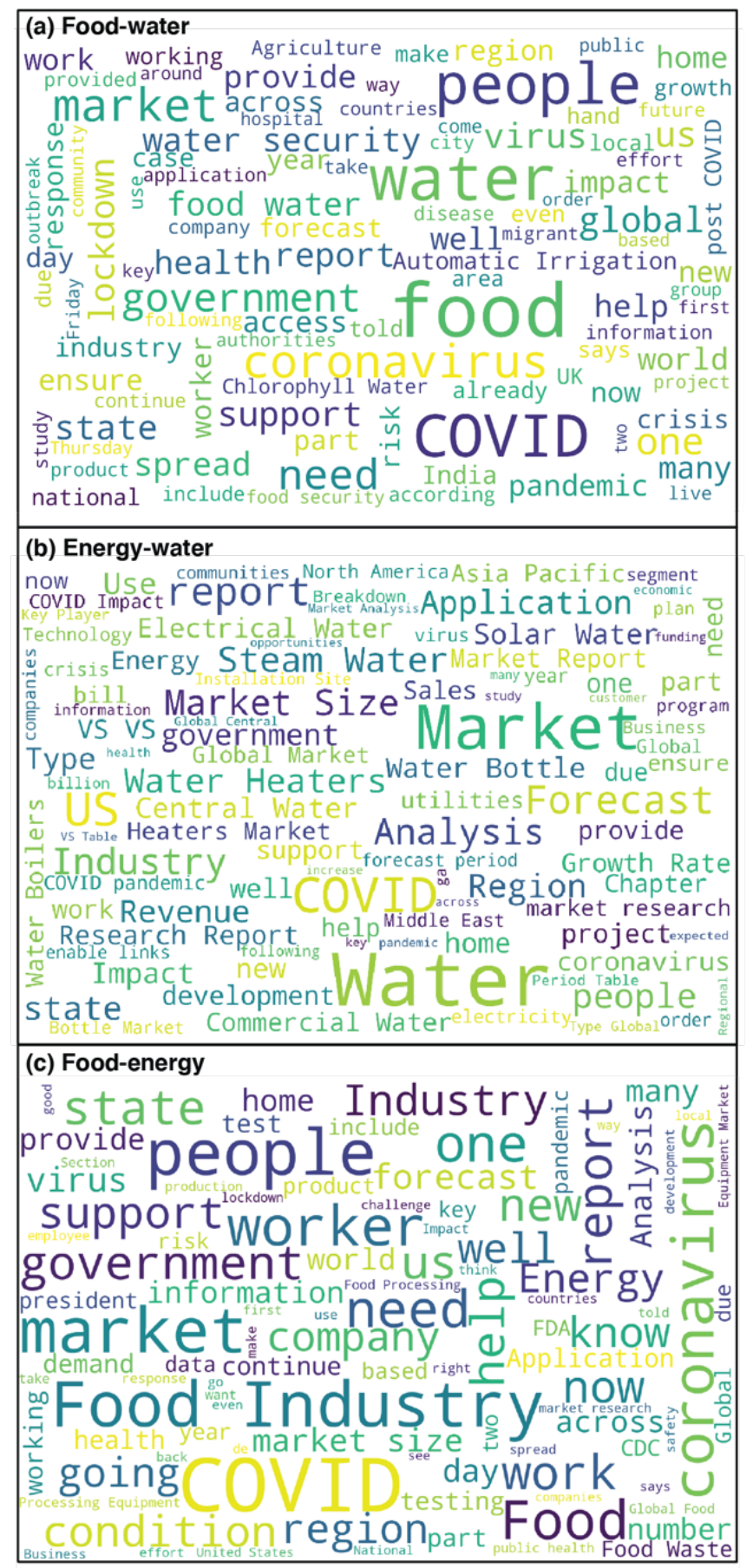

Figure S2: Most frequent words in (a) food-water, (b) energy-water and (c) food-energy groups of news/media articles. 
Table S7: Terms by semantic similarity to "government" for groups of popular press articles

\begin{tabular}{cccc}
\hline Rank & Food-Energy & Food-Water & Energy-Water \\
\hline 1 & pandemic & pandemic & report \\
2 & virus & virus & state \\
3 & president & country & virus \\
4 & country & uk & lockdown \\
5 & company & lockdown & country \\
6 & us & state & crisis \\
7 & administration & coronavirus & world \\
8 & world & food & market \\
9 & outbreak & world & outbreak \\
10 & report & crisis & vendors \\
11 & market & market & lockdown \\
12 & department & centre & study \\
13 & food & disease & forecast \\
14 & disease & industry & region \\
15 & public & region & situation \\
16 & agency & outbreak & support \\
17 & state & city & order \\
18 & time & migrants & time \\
19 & hospital & health & people \\
20 & day & future & funding \\
\hline
\end{tabular}


Table S8: Terms by semantic similarity to "market" for groups of popular press articles

\begin{tabular}{cccc}
\hline Rank & Food-Energy & Food-Water & Energy-Water \\
\hline 1 & industry & pandemic & industry \\
2 & virus & country & revenue \\
3 & country & virus & report \\
4 & food & government & pandemic \\
5 & us & uk & sales \\
6 & report & lockdown & country \\
7 & production & outbreak & virus \\
8 & pandemic & world & crisis \\
9 & coronavirus & coronavirus & size \\
10 & president & crisis & global \\
11 & outbreak & centre & research \\
12 & growth & food & coronavirus \\
13 & lockdown & area & future \\
14 & world & city & growth \\
15 & company & house & trends \\
16 & revenue & state & study \\
17 & administration & growth & state \\
18 & disease & disease & region \\
19 & public & industry & department \\
20 & government & globe & segment \\
\hline
\end{tabular}

